\title{
JOB AND ORGANIZATIONAL PREDICTORS OF MOBILITY INTENTIONS IN THE FEDERAL PUBLIC SERVICE OF CANADA
}

\author{
by \\ Holly Theresa-Marie Holmes \\ B.A., York University, 2008

\begin{abstract}
A thesis submitted to
the Faculty of Graduate and Postdoctoral Affairs

in partial fulfillment of the requirements for the degree of
\end{abstract} \\ Master of Arts \\ in \\ Psychology
}

Carleton University

Ottawa, Canada

C2011, Holly Holmes 
Library and Archives
Canada

Published Heritage

Branch

395 Wellington Street

Ottawa ON K1A 0N4

Canada
Bibliotheque et

Archives Canada

Direction du

Patrimoine de l'édition

395 , rue Wellington

Ottawa ON K1A ON4

Canada
Your file Votre référence ISBN: 978-0-494-83099-4

Our file Notre référence

ISBN: 978-0-494-83099-4
NOTICE:

The author has granted a nonexclusive license allowing Library and Archives Canada to reproduce, publish, archive, preserve, conserve, communicate to the public by telecommunication or on the Internet, loan, distribute and sell theses worldwide, for commercial or noncommercial purposes, in microform, paper, electronic and/or any other formats.

The author retains copyright ownership and moral rights in this thesis. Neither the thesis nor substantial extracts from it may be printed or otherwise reproduced without the author's permission.
AVIS:

L'auteur a accordé une licence non exclusive permettant à la Bibliothèque et Archives Canada de reproduire, publier, archiver, sauvegarder, conserver, transmettre au public par télécommunication ou par l'Internet, prêter, distribuer et vendre des thèses partout dans le monde, à des fins commerciales ou autres, sur support microforme, papier, électronique et/ou autres formats.

L'auteur conserve la propriété du droit d'auteur et des droits moraux qui protège cette thèse. $\mathrm{Ni}$ la thèse ni des extraits substantiels de celle-ci ne doivent être imprimés ou autrement reproduits sans son autorisation.
In compliance with the Canadian Privacy Act some supporting forms may have been removed from this thesis.

While these forms may be included in the document page count, their removal does not represent any loss of content from the thesis.
Conformément à la loi canadienne sur la protection de la vie privée, quelques formulaires secondaires ont été enlevés de cette thèse.

Bien que ces formulaires aient inclus dans la pagination, il n'y aura aucun contenu manquant.

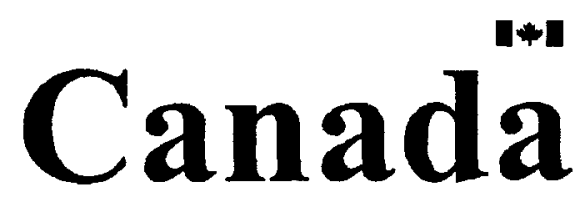




\title{
EXPLORING MOBILITY INTENTIONS
}

\begin{abstract}
The steady increase in employee mobility within the federal Public Service of Canada has been noted as an area of concern due to the inability to predict or plan for voluntary inter-departmental moves. Guided by Becker's (1960) theory of commitment and March and Simon's (1958) ease and desirability theory, the present research examined intention to change departments, along with demographic, job-related and organizational-level predictors of voluntary intra-organizational mobility. The results suggest that the demographic, job-related, and organizational-level predictors influence employees' intention to change departments within the Public Service. The most important factors associated with employees intending to remain in or leave their department were person-job fit and organizational commitment. With the scarcity of research conducted in a public service context in this domain, this research contributes to knowledge and sets the stage for future research to build on.
\end{abstract}




\section{EXPLORING MOBILITY INTENTIONS}

\section{Acknowledgements}

I would like to express my sincerest gratitude to my supervisors Dr. Tzvetanka Dobreva-Martinova and Dr. Janet Mantler for their guidance, support, and encouragement over the past two years. I feel very fortunate to have worked with supervisors who have such a wealth of knowledge and experience in the field of Industrial/Organizational Psychology. I have learned so much from both of you, thank you! I would also like to thank my committee, Dr. Avi Parush, Dr. Bernadette Campbell, Dr. Linda Schweitzer, and Dr. Tim Pychyl for their insightful comments and questions. I would like to express my appreciation to my amazing family for always being supportive of my dreams, believing in my ability to shine even during difficult circumstances, and for their unconditional love. I especially would like to thank my mum for inspiring me to dream big and to believe that I can achieve anything. Thank you for always being on my side and loving me toooo much. To my sister, Carrie, thank you for being my best friend and for always looking out for me. I would like to thank my dad for his encouragement through this process and for moving me and all my stuff multiple times. Taylor, thank you for being such a goof! To my grandparents, thank you for playing such an important role in my life. I would like to also thank my grandpa, who wasn't able to see me complete my degree, for always having the kettle ready and for his ever present support that will continue throughout all of my future endeavours.

To my friends, especially Krystal, thank you for standing by me, supporting me, and understanding that sometimes I could only be home in spirit.

I would like to acknowledge the Treasury Board Secretariat, my employer, who supported my research venture and Jean-Mitchel at Statistics Canada for his help with STATA. Thank you once again to everyone who supported me through this degree. I am truly blessed to be surrounded by such supportive and caring people. 


\section{EXPLORING MOBILITY INTENTIONS}

\section{Table of Contents}

Abstract ................................................................................................................. ii

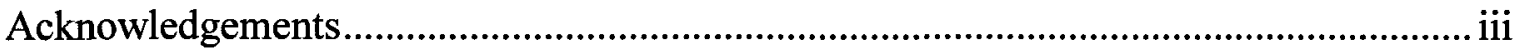

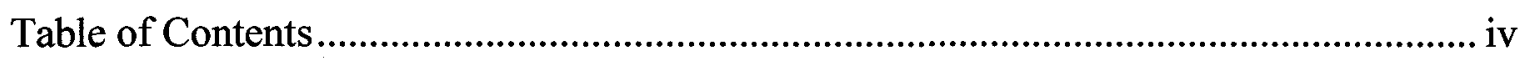

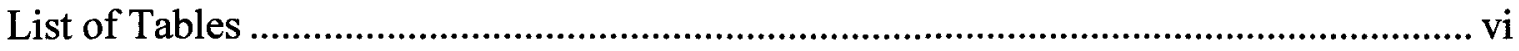

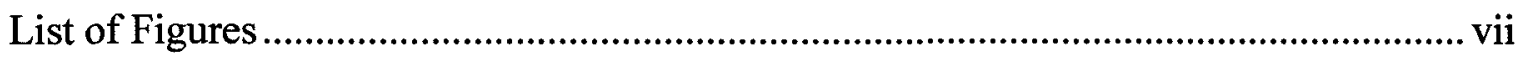

List of Appendices ............................................................................................. viii

Job and Organizational Predictors of Mobility in the Federal Public Service of Canada .. 1

Defining Mobility .............................................................................................. 2

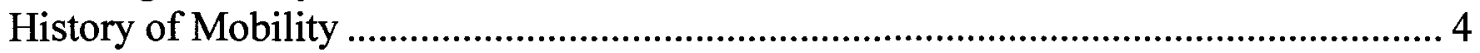

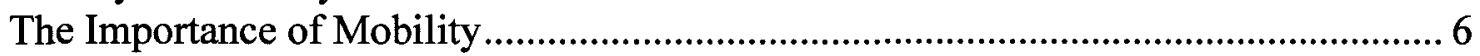

Mobility in the Federal Public Service .................................................................... 10

Mobility in the Canadian Federal Public Service ................................................... 13

Becker Theory of Commitment and the Federal Public Service of Canada................. 15

Predictors of Mobility ............................................................................................ 19

Predictors of intra-organizational mobility...............................................20

Predictors of inter-organizational mobility..................................................23

Current Study Research Questions and Hypotheses............................................ 26

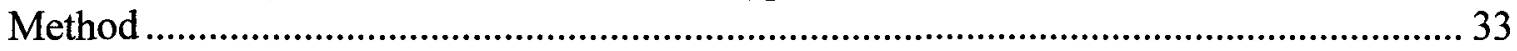

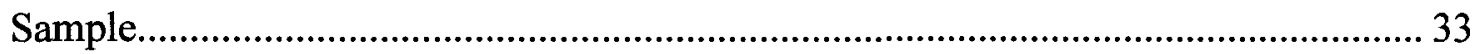

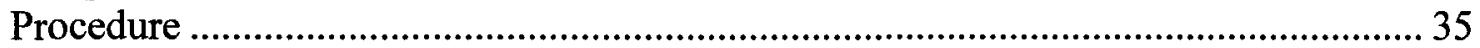

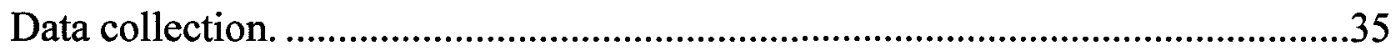

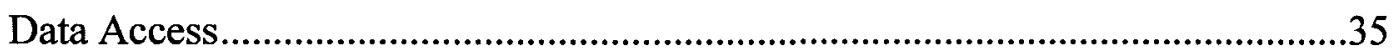

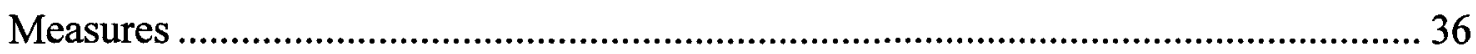

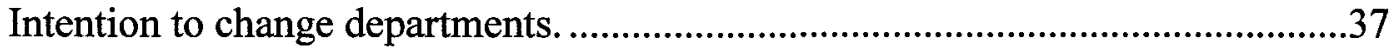

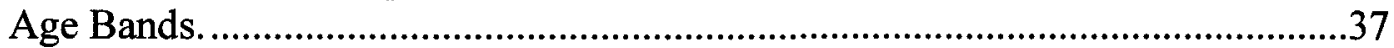

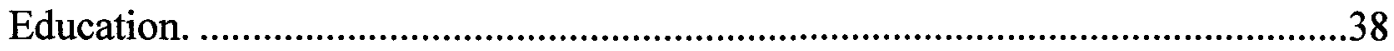

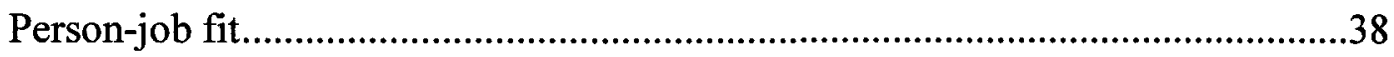

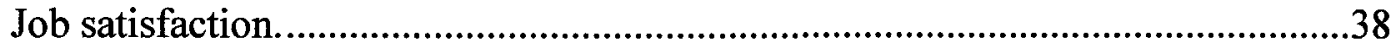

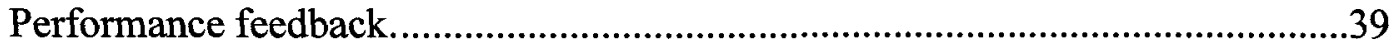

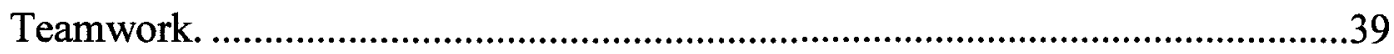

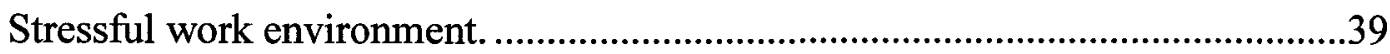

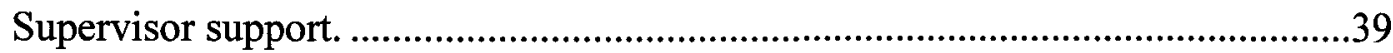

Organizational commitment......................................................................40

Career development and opportunities. .......................................................40

Results. 


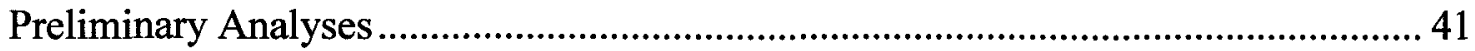

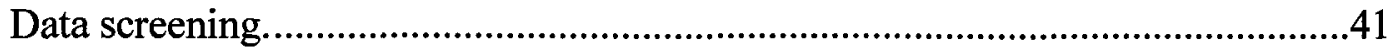

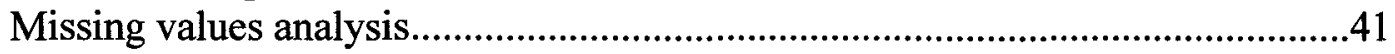

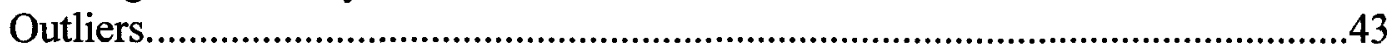

Descriptive and correlational analyses.................................................................44

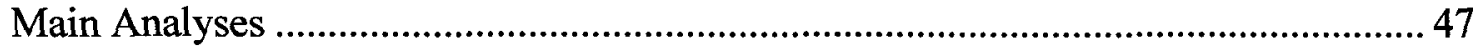

Demographic predictors of intention to change departments ...............................47

Job-related predictors of intention to change departments .........................................50

Organizational-level predictors of intention to change departments .......................54

Person -job fit as a moderator between stressful work environment and intention to change departments...............................................................................................61

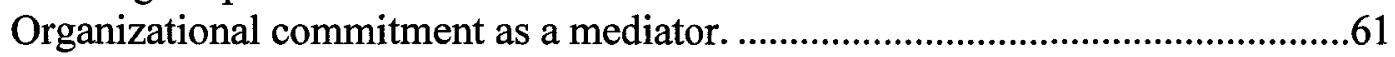

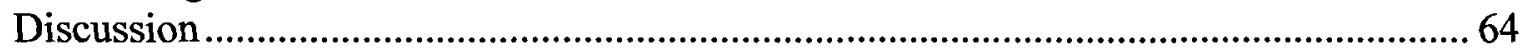

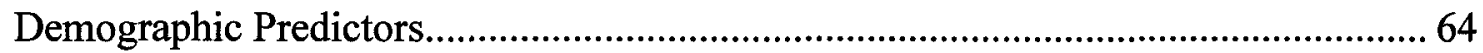

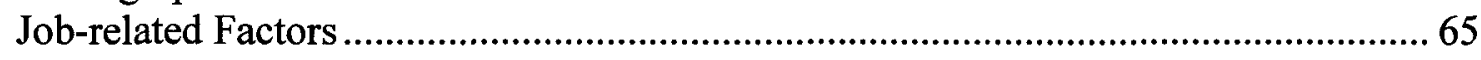

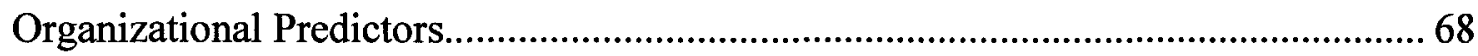

Theoretical Contributions ........................................................................................... 70

Methodological Contributions ……........................................................................... 72

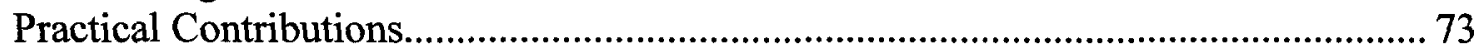

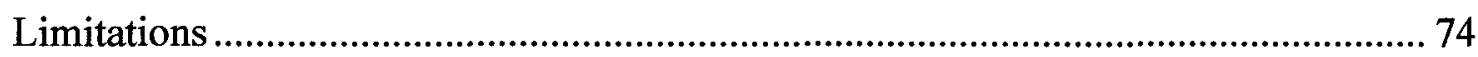

Future Research and Conclusions........................................................................ 75

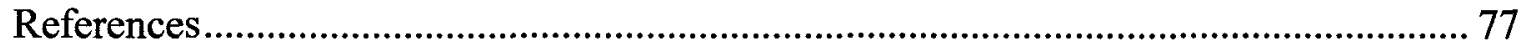

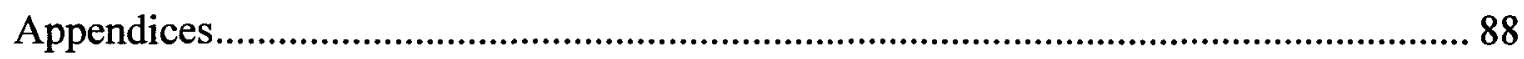

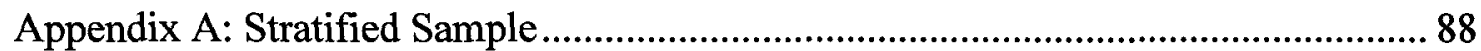

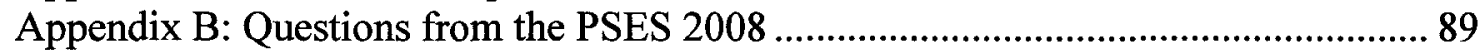

Appendix C: Assumption Testing for Logistic Regression ........................................... 92 
EXPLORING MOBILITY INTENTIONS

\section{List of Tables}

Table 1. Correlations, Means, Standard Deviations, and Reliabilities for Study Variables

Table 2. Direct Logistic Regression: Demographic Factors and Intention to Change

Departments

Table 3. Direct Logistic Regression: Job-related Predictors and Intention to Change

Departments

Table 4. Sequential Logistic Regression: Demographic and Job-Related Factors, and

Intention to Change Departments 54

Table 5. Direct Logistic Regression of Organizational-level Predictors and Intention to

Change Departments. 56

Table 6. Sequential Logistic Regression with Organizational-level Predictors and

Intention to Change Departments 58

Table 7. Sequential Logistic Regression with Demographic, Job-related, and

Organizational-level Predictors and Intention to Change Department. 60 


\section{EXPLORING MOBILITY INTENTIONS}

\section{List of Figures}

Figure 1: Conceptual Model of Intra-Organizational Mobility ........................................ 28

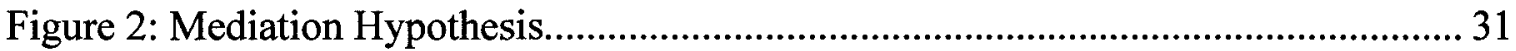

Figure 3: Mediation Model for Organizational Commitment with Paths and Regression

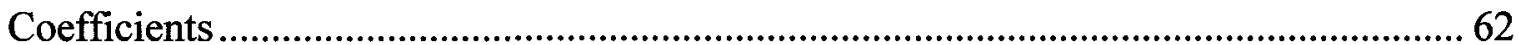




\section{EXPLORING MOBILITY INTENTIONS}

\section{List of Appendices}

Appendix A: Stratified Sample .................................................................................. 88

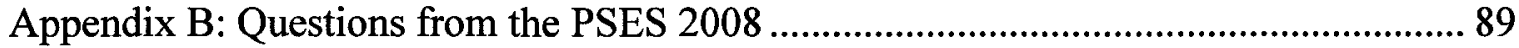

Appendix C: Assumption Testing for Logistic Regression ............................................... 92 


\section{Job and Organizational Predictors of Mobility Intentions in the Federal Public \\ Service of Canada}

Job mobility is a prevalent topic in the academic literature as there is a vast amount of research on the determinants of, and preferences for, employee movement in and out of organizations (e.g., Cho, Johanson \& Guchait, 2009; Curry, 2009; Ito \& Brotheridge 2005; Liu, Liu \& Hu, 2010; Ng, Sorensen, Eby, \& Feldman, 2007). Job mobility has been studied as inter-organizational moves (Cho et al., 2009; De Lange, De Witte, \& Notalers, 2008; Kallenberg \& Mastekaasa, 2001) and intra-organizational moves (Kondratuk, Hausdorf, Korabik, \& Rosin, 2004; Ito, 2003; Otto, DetteHagenmeyer, \& Dalbert, 2010) in both private and public sectors. Researchers and organizations alike continue to study mobility because of its links to organizational effectiveness and its importance for strategic human resource planning.

The majority of the research on job mobility has been conducted within the private sector. Research in the private sector has centered around both inter- and intraorganizational mobility by examining turnover, promotions, lateral, and downward moves with most of the intra-organizational mobility research examining involuntary movements. Although some mobility research has been conducted in the public sector, most of this research has focused on schools and hospitals to examine turnover and its relationship with person-organization fit, organizational commitment, and organizational support and has found a negative relation between turnover and these organizational constructs (Cho, Johanson, \& Guchait, 2009; Ito \& Brotheridge 2005; Liu, Liu, \& Hu, 2010). The research on public sector mobility has also found a positive association of mobility intentions with supervisor support, career adaptability, and disappointment with 
promotion opportunities (Cho, Johanson, \& Guchait, 2009; Ito \& Brotheridge, 2005; Ito, 2003). While there is some research on mobility in the public sector, very few mobility studies conducted within a government setting have been reported in the academic literature (Ito, 2003; Ito \& Brotheridge, 2005; Liu, Liu, \& Hu, 2010).

The purpose of the present research was to examine job-related and organizational-level predictors of voluntary intra-organizational mobility in the federal Public Service of Canada by focusing on employees who reported intent to leave their department in order to pursue a job in another Canadian federal department or agency. There is a gap in the existing literature on voluntary intra-organizational mobility as very few studies have examined the predictors of voluntary intra-organizational mobility. Moreover, the population in this study is distinct because employees in the federal Public Service have the ability to leave their department while still remaining employed with the Government of Canada. This is the overall trend in the Canadian Public Service as once employees begin a career as federal public servants they rarely leave until they are ready to retire (PSC, 2008). This population is different from the population that has been studied in the majority of the research conducted with private or public sector employees as the intra-organizational moves in the Canadian federal government are voluntary. Employees decide whether they want to move upward, downward, or laterally through applying to internal competitions.

\section{Defining Mobility}

Job mobility refers to patterns of inter- and intra-organizational movement over an individual's career (Ng, Sorensen, Eby, \& Feldman, 2007). Inter-organization mobility is the movement from one organization to another and is divided into voluntary and 
involuntary mobility (Kallenberg \& Mastekaasa, 2001). Inter-organizational mobility is aligned with the attrition and retention literature. Voluntary inter-organizational mobility is studied in terms of employees quitting. Involuntary inter-organizational mobility is studied as layoffs or other forms of employee dismissal. Intra-organizational mobility is the movement of employees within the same organization. Intra-organizational mobility is studied in terms of upward moves (promotions), downward moves (demotions), and lateral moves (Kallenberg \& Mastekaasa, 2001). Intra-organizational mobility is also studied as job transfers and job rotations (Liljegren \& Ekberg, 2009; $\mathrm{Ng}$ et al., 2007). In general, the main distinctions between the mobility types are based on where the employee is moving to (into or out of the organization) and who is deciding the move (employee or management).

Jackofsky and Peters (1983) proposed that turnover be conceptualized to include both inter-organizational and intra-organizational mobility. The authors believed that the two concepts provided a more appropriate criterion for testing turnover, as even individuals who stayed in their organization but left their job would be classified as leavers. These authors argued that intra-organizational mobility should be included when examining turnover because when employees are dissatisfied with their current position or wish to attain more valued work-outcomes they may be able to accomplish these goals by changing jobs, not necessarily organizations. Jackofsky and Peters (1983) also clarified that only voluntary turnovers would be classified as such. Todor (1980 as cited in Jackofsky \& Peters, 1983) pioneered the intra-organizational mobility research finding that employees who wanted to but were not able to transfer had less job satisfaction, less company loyalty, and greater turnover intention compared to those able to transfer, or 
those who had not requested a transfer. Therefore Todor concluded that the antecedents of turnover and internal voluntary transfers were similar because internal transfers could also be used as a withdrawal mechanism.

\section{History of Mobility}

Traditionally, employees worked for one organization throughout their career in a position for which they qualified early in life (Otto, Dette-Hagenmeyer, \& Dalbert, 2010), which was known as the "bounded" career (Arthur, 1994). The only occupational changes that occurred in this type of career tended to be associated with upward mobility (Otto et al., 2010). The traditional career was based on an employee moving up the vertical ladder through a series of promotions (De Vos, Bewettinck, \& Buyens, 2008). The incremental upward movement paralleled one's tenure in their organization (Arthur, Khapova, \& Wilderom, 2005) and was associated with increases in authority, prestige, and rewards (Garavan \& Coolahan, 1996). The clear career path made employees loyal to their organization.

However, the 1980s brought about radical changes with companies undergoing restructuring and downsizing (Spell \& Bloom, 2000). Organizations are now smaller and flatter (Schermerhom, 2009; Spell \& Bloom, 2000) and therefore opportunities for promotions are becoming scarce (De Vos et al., 2008). Employees are no longer waiting to be promoted within their organization, but are rather looking to advance their careers by moving to another organization. Moreover, there has been an increase in contingent workers, which includes contract employees, temporary help workers, agency staff, and part-time workers (Macdonald, 2011; Way, Lepack, Fay, \& Thacker, 2010). Contingent workers are more mobile than permanent employees as they are generally hired for a set 
amount of time (De Cuyper \& De Witte, 2007; Macdonald, 2011; Way et al., 2010) to complete, or aid in the completion of, a project or to provide specialized knowledge (Macdonald, 2011). Therefore, employees in general are more mobile today than they have been in the past due to the increase in contingent work and deviations made from the traditional career path.

The fewer available full-time positions and the lack of job security have led to employees taking an independent approach to their career (Authur \& Rosseau, 1996; Ng, Sorensen, Eby, \& Feldman, 2007) through voluntary mobility. Therefore, employees are more willing to move within their organization (intra-organizational mobility) through promotions, lateral moves, transfers, and job rotations or outside of their organization (inter-organizational mobility) to ensure they are progressing through their career at an acceptable pace or to find better working conditions. Moreover, employees are also more willing to accept job transfers and job rotations in situations of downsizing (involuntary mobility).

The fact that employees are more mobile now than they have been in the past was documented by the United States Department of Labor (2004) reporting that Baby Boomers held approximately 10 jobs between the ages of 18 and 38 ( $\mathrm{Ng}$ et al., 2007). The increase in mobile employees can also be addressed through examining employee tenure with an organization. Farber (1997a, 1997b, 1998) noted, based on the Department of Labor's Current Population Survey (1996), that in 1996, 34.5\% of employees aged 3564 had at least a ten-year tenure with their current organization and $20.9 \%$ of those $45-64$ had at least 20 years of service with their current organization. However, the author also noted that $19.1 \%$ of workers aged $20-64$ had only been with their current employer for 
less than one year. It was reported that "the incidence of long-term employment ... fell substantially after 1993, to its lowest level since 1979" (Farber, 1998, p.12). This statement was built upon by further research indicating that the decline in long-term employment is prevalent irrespective of education. Gregg and Wadsworth (2002) noted that decline of long-term employment had also been noticed in the United Kingdom. A decline in tenure with an organization as noted by the decrease in long-term employment provides support that employees are more mobile now than they have been in the past.

\section{The Importance of Mobility}

The importance of mobility stems from the loss in profit and efficiency that is frequently associated with it. Employees who have the intent to leave their organization are more likely to engage in withdrawal behaviours (Hayes et al., 2006), which can manifest as increased absenteeism, lateness, decreased motivation, and a lack of performance, all of which reduce productivity and organizational effectiveness (Hayes et al., 2006). The Gallup Institute estimates that disengagement (a form of withdrawal) costs the United States approximately 300 billion dollars per year (Wallace \& Trinka, 2009). Furthermore, research has consistently shown that turnover intention is the best predictor of actual turnover even though the strength of the association is moderate $(\rho=.38)^{1}$ (Griffeth, Hom, \& Gaertner, 2000). As the cost of replacing an employee is drastic and can cost an organization up to $100 \%$ of the employee's salary (Ramlall, 2003), identifying the factors that keep an employee from leaving are imperative to the success of an organization.

\footnotetext{
1 “ $\rho=$ sample size weighted mean correlation corrected for measurement error in the predictor" (Griffeth, Hom, \& Gaertner, 2000, p.475).
} 
Blanchard, Welbourne, Gilmore, and Bullock (2009) recommend that organizations foster active engagement in their workforce as it was shown to be the strongest driver in the relationship to organizational commitment and job satisfaction (Blanchard et al., 2009). Schaufeli, Bakker, and Van Rhenen (2009) showed a negative relationship between engagement and withdrawal behaviours, namely sick leave. Organizational commitment and job satisfaction have been shown to have a negative relationship with turnover (Tett \& Meyer, 1993). Cho, Johanson, and Guchait (2009) found that perceived organizational support was a key determinant in an employee's intention to stay with their organization. Moreover, employees stay in their organizations when their expectations are met or exceeded, when they have good working conditions, fair remuneration, job security, and good relationships with colleagues and managers (Curry, 2009). Therefore, it is important for organizations to combat the negative withdrawal behaviours through various initiatives to foster perceived organizational support, engagement, satisfaction, and commitment in order to increase one's intent to stay.

Mobility is also important in organizations because it has many beneficial properties. Inter-organizational mobility can be viewed as an important practice at the societal level as it may enhance the growth of intellectual capital through the diffusion of knowledge, skills, innovation, perspectives, and technology between firms (Ituma \& Simpson, 2009; Ng et al., 2007) and within firms. In large companies there are usually barriers between departments, units, locations or functions that are difficult to break, however intra-organizational mobility can foster cooperation between these areas (De Vos, Bewettinck, \& Buyens, 2008). 
Mobility is not only beneficial to the organization, but also to the individual as employees can learn valuable knowledge, skills, and competencies when moving within or outside an organization (De Vos et al., 2008). Career mobility is important because of its association to commitment, satisfaction, and intent to stay (De Vos et al., 2008; Hsu et al., 2003). All of the benefits associated with mobility can impact a company's competitiveness (Liljegren \& Ekberg, 2009). However, there is a fine balance between some mobility and too much mobility. Therefore, human resources planning on mobility is crucial (Greenhaus, Callanan, \& Godshalk, 2000; Ng et al., 2007).

It is especially important to understand and manage voluntary mobility as it is difficult to anticipate it and plan for it in comparison to involuntary mobility whereby the organization decides who moves and when they move. When involuntary mobility occurs in an organization, the employer is able to plan for the amount of resources that need to be allocated for hiring new employees and training these employees. However, with voluntary mobility, the employer is unaware of an employee's exit until (commonly) two weeks prior to the exit. Thus, organizations need to understand and act on employees' mobility intentions before those intentions become actual turnovers. This is particularly important for organizations such as the federal Public Service of Canada that provide ample opportunities for voluntary intra-organizational mobility.

The federal Public Service of Canada is an ideal organization in which to conduct the needed research on voluntary intra-organization mobility as it employs a wide variety of workers all across Canada and is currently experiencing high intra-organizational mobility (PSC, 2008). In addition to the contribution to the limited knowledge in this area, the understanding of the factors that are related to one's intention to leave their 
department in pursuit of a job in another department could inform the Government of Canada's efficient human resource planning as well as the development of targeted retention initiatives.

The study of mobility in the public sector is important because it is composed of many important organizations that help run cities, provinces/states, and countries; hospitals, academic institutions, schools, and government departments and agencies all are part of the public sector. The public sector has different characteristics than the private sector that make it a unique and interesting domain of study. For example, the public sector boasts greater job security and a more relaxed climate than the results/efficiency orientated private sector (Koch \& Steers, 1978). Also, it is important to study the public sector because of the clear organizational structure, stable work categories, and classifications (McDonald, Brown, \& Bradley, 2004).

The federal Public Service of Canada is different from other unionized organizations in the public sector, such as universities or hospitals, for various reasons. For example, employees can move geographically and the move remains at low risk to their career and at a low cost as they keep their pay, pensions, and benefits intact. Also, their years of continuous service are not interrupted and they do not lose any accumulated vacation time or sick leave. Moreover, employees in the federal Public Service can change their field of work; for example, a research analyst working at Health Canada could change to a policy analyst working at the Treasury Board of Canada Secretariat, or to a personnel administration officer at Transport Canada. Even when changing to a different job or field, employees are able to make these changes fairly easily and at no cost to them. The federal Public Service is a major employer that spans the entire county 
with a wide spectrum of classifications and positions, which allows for building a breadth of knowledge and skills among the workforce that can be applied to many different kinds of jobs. In contrast, in a hospital setting a certified radiation therapist has a fairly specific job in which the skills could not be easily transferable to another service.

\section{Mobility in the Federal Public Service}

Whereas some mobility research has been conducted at the state level (APSC, 2003; Sinnott, Madison, \& Pataki, 2002; Trendle \& Tunny, 2003) the majority of the limited research on mobility in the public service has focused on the federal Public Service in various countries. The lack of mobility research in a public service context, reported in the academic literature, creates a niche for examining mobility in the federal Public Service, in order to understand its motivation and consequences in this important employment domain. The federal Public Service in each country employs a large amount of employees and has a major impact on society, therefore making it a key organization to study.

Mobility within and outside of the federal Public Service is an area of interest for many countries worldwide. Specifically, Canada, the United States, Australia, and the United Kingdom's public services have all spent time and resources studying mobility within their respective federal Public Service. However, these efforts have focused primarily on the rates of mobility rather than on understanding the job-related and organizational-level predictors that are associated with mobility within these public services. Whereby some federal public services are looking to decrease the amount of intra-organizational mobility (e.g., Canada) as identified in a report by the Public Service Commission (PSC, 2008) and through initiatives (e.g., development programs) created to 
keep employees in their respective departments (TBS, 2011), others are trying to increase mobility by promoting movement within and between government departments (e.g., the United States and Australia). The various federal public services measure different aspects of mobility (e.g., turnover, intakes, separations) or produce an overall mobility statistic. However, as the mobility statistics produced for each country differ in their methodologies, comparisons are difficult.

The Australian federal Public Service is struggling with limited mobility between and within agencies. Initiatives have been created in Australia to promote mobility within the federal Public Service because the Australian Public Service understands the benefits associated with mobility and is trying to increase and encourage the movement of employees. Mobility in the Australian Public Service fell for both promotions and transfers during the 2008-2009 period (APS, nd). Overall mobility rates were down from $3.1 \%$ (females) and $2.6 \%$ (males) in $2007-2008$ to $2.4 \%$ and $2.1 \%$ in $2008-2009$ for females and males respectively. The State of the Service (2008-2009) report noted that $97 \%$ of promotions occur within one's department and that only $2 \%$ of promotions and transfers are to other departments. It is interesting that employees do not take advantage of mobility options. The tendency for individuals in the Senior Executive Services (SES) classification of the Australian federal Public Service to spend their career in one agency is increasing (34.7\% in 2000 to $45.4 \%$ in 2009$)$ (APS, nd).

The Australian federal Public Service (APS) wants to increase movement of employees to allow for employees to gain skills and experience. APS has introduced "Branching Out", an on-line registration system for federal employees who are looking to move within the Australian Public Service (APS, 2011). The registration is for those 
looking to move as an on-going move (will not return to home agency) or for a temporary move (APS, 2011). The push to increase mobility in the Australian Public Service is understandable since, at the current rate of about $2 \%$, the organization is experiencing a particularly low voluntary intra-organizational mobility (APS, nd).

The United States of America has also taken an interest in promoting mobility. The US Office of Personnel Management (IPA) (2010) has developed the Intergovernmental Personnel Act Mobility Program available to federal employees. The program encourages mobility throughout the service by granting permission for temporary assignments of employees to move to other federal, state, and local governments as well as to universities, colleges, and other authorized entities (USOPM, 2010). The purpose of the IPA Mobility Program is to support innovation, solve problems through the diffusion of shared resources and expertise, and improve the quality of the Public Service. There are rigid restrictions on using the mobility program such that an employee is only able to serve 6 years of his or her career on IPA temporary assignments and that after the assignment (usually 2, but can last up to 4 years) the employee must serve the same length of time in the federal service.

Mobility does not appear to be as pressing a concern in the United Kingdom Civil Service as no reports (to this author's knowledge) have been published. However, there is a mobility section in the Civil Service Management Code (CSMC) (2010) that outlines conditions of mobility inside and out of the civil service. There are different kinds of moves available to federal employees with some being the department/agency's decision and some (secondment) being the employee's decision. Although no published mobility rates were uncovered, the Civil Service People Survey (2010) and the Office for National 
Statistics (2010) provide rates on intention to leave, and actual entrants and leavers rates. Based on the Civil Service People Survey (2010) $8 \%$ of employees wanted to leave their organization as soon as possible, followed by $11 \%$ indicating intent to leave within 12 months. Most employees wanted to remain with their organization for at least the next 3 years (55\%) or for at least the next 12 months (26\%). Furthermore, entrant and leaver statistics published by the Office for National Statistics indicate that there were more leavers $^{2}(39,171)$ than entrants $(39,005)$ in 2010 (ONS, 2010).

\section{Mobility in the Canadian Federal Public Service}

The 2006-2007 Annual Report of the Public Service Commission (PSC) outlined that the level of mobility in the Canadian federal Public Service is an area of concern. A study was initiated by the PSC based on the growing need for research on the movement of federal employees within and outside the Public Service (PSC, 2008).

The report titled Study on Mobility of Public Servants (2008) outlined that from 2004 to 2008 mobility had been steadily increasing. In $2004 / 2005$ the mobility rate for the federal Public Service, which includes intakes, separations, and internal movements, was at $30 \%$ whereas by $2007 / 2008$ the amount of employee movement was up to $42 \%$ (PSC, 2008). Based on reports indicating that specific occupational groups (e.g., the Economics, Statistics, \& Sociology group) were the most mobile, the Government of Canada has started employee development programs. These development programs allow for upward progression within one's department through developing specific competencies (TBS, 2011). Therefore, as countries like the U.S. and Australia are trying

\footnotetext{
${ }^{2}$ The Office of National Statistics in the United Kingdom produces Bulletins whereby they address entrants and leavers. The report does not address whether the leavers are voluntary, involuntary, or retirees. This provides an example of why the rates cannot be compared between public services.
} 
to encourage mobility through key initiatives, Canada is trying to keep its federal public servants in a position for longer in order to avoid the pitfalls of too much mobility.

The federal Public Service of Canada is a key population to study, as it is an organization that employs approximately 270,000 people working in various departments and agencies nation-wide. The difference between a central agency and a department has been outlined as,

"[an agency] is generally used to designate organizations that have a central coordinating role. These organizations work across government departments to provide advice to the prime minister and Cabinet and to ensure policy coherence and coordination on their behalf. Central agencies have either formal or informal authority over other departments and often direct their actions. Line departments, on the other hand, provide services directly to Canadians and do not have the authority or mandate to direct other departments in their operations" (Smith, 2009, p. 1).

The organizational structure of the federal Public Service is also different from many other private or public sector organizations as employees are able to change departments without changing employers. As employees keep the same employer (i.e., the Government of Canada), have continuous pay, pension, and benefits, their movements should be classified as intra-organizational mobility. However, because they are moving to a different department or agency with different colleagues, managers, and priorities, the reasons for the moves were hypothesized to also be aligned with those identified in the inter-organizational mobility research. The research conducted on interorganizational mobility (i.e., turnover) is important as the Public Service Employee Survey (the measure used in this study) identifies employees' affiliation to their department, not the federal Public Service in its questions and therefore, it was expected 
that the predictors of inter-organizational mobility would also be the predictors of intraorganizational mobility. The Government of Canada has indicated that the mobility rate within the federal Public Service is an area of concern; thus the need to examine why employees are moving is also important from an operational perspective. Therefore, the current study built on research that has been conducted in government settings (e.g., Ito, 2003; Ito \& Brotheridge, 2005), and the research in non-government settings that has explored factors associated with intra- and inter-organizational mobility. The present study examined both job-related and organizational-level predictors that were conceptualized to relate to intention to change departments, thus aiming to elucidate whether the job or the organizational factors have the strongest association with voluntary job mobility in the federal Public Service of Canada. While the rates of voluntary mobility in the federal Public Service of Canada are known, the job and organizational factors that are associated with voluntary mobility are not well understood. The Becker theory of commitment (1960) and March and Simon's ease and desirability theory (1958) are conceptual frameworks that could help to understand voluntary mobility in the federal Public Service of Canada and the factors associated with it.

\section{Becker Theory of Commitment and the Federal Public Service of Canada}

In 1960, Becker proposed a theory of commitment according to which people make side-bets to make themselves more committed to some course of action. Becker (1960) viewed commitment as behavioural, which contrasted the view that commitment was attitudinal/affective (McGee \& Ford, 1987). Becker believed that "commitments come into being when a person, by making a side-bet, links extraneous interests with a consistent activity" (p. 32). Becker suggested that side-bets fall into five general, non- 
exclusive, categories including generalized cultural expectations, self-presentation concerns, interpersonal bureaucratic arrangements, individual adjustment to social positions, and non-work concerns. When employees make a side-bet, it is to protect them from departing from the course of action (e.g., staying with an organization). Therefore, side-bets make an individual more embedded in their course of action by making it more costly for them to veer off course.

In an organizational realm, individuals who have spent a lot of time with an organization making friends, earning respect from colleagues and management, or contributing to their pension, will have these factors as side-bets. Therefore, employees do not leave the organization because they perceive it as too costly for them to leave.

The idea of remaining with an organization because it is too costly to leave has more recently been examined as "continuance commitment" (Allen \& Meyer, 1990). When factors influence an employee's perception of the costs associated with leaving, continuance commitment is expected to develop. McGee and Ford (1987) factor analyzed the Meyer and Allen (1984) commitment scale which was composed of affective and continuance commitment and found that continuance commitment was made up of two facets, high sacrifice and low alternatives. ${ }^{3}$ The high sacrifice facet parallels Becker's side-bet theory of commitment, which is conceptualized as a behavioural commitment to the organization (McGee \& Ford, 1987). Interestingly, Meyer, Stanley, Herscovitch, and Topolnytsky (2002) noted that high sacrifice was more strongly associated to turnover intention than the low alternatives facet of continuance commitment.

\footnotetext{
${ }^{3}$ Meyer \& Allen's three component conceptualization of organizational commitment was introduced in 1991. This is where the third component of normative commitment surfaced (Meyer \& Allen, 1991).
} 
The idea of employees who are bounded to their organization as they believe the cost of leaving is too great (high sacrifice) is worth exploring within the context of the federal Public Service of Canada. The federal Public Service is a highly attractive organization, offering job security and competitive pension and benefit packages to attract job seekers (PSC, 2011; TBS; 2011), thus many applicants would be willing to take any job in order to enter the federal Public Service. The Public Service Commission noted that in 2006-2007 more than 260,000 individuals' submitted more than 1.07 million applications to 5,671 advertisements posted on the Government of Canada external job website (www.jobs.gc.ca) (PSC, 2007). This trend continued in 2007-2008 whereby over 279,000 applicants applied to approximately 5,000 job postings through over 1 million applications (PSC, 2008).

The high number of people applying to various federal jobs is paralleled with a very low number of people who are leaving the federal Public Service for reasons other than retirement. During the 2007-2008 fiscal year 2,340 individuals voluntarily left the Government of Canada, which is less than $1 \%$ of the workforce. During the 2009-2010 fiscal year reports indicated that the amount of individuals who left the federal Public Service specifically to move to a separate employer was $560^{4}$. Therefore, it seems that the interest in working for the federal Public Service is definitely not fading, and attraction and retention are not areas of concern. Based on the exit statistics, it appears that

\footnotetext{
${ }^{4}$ In contrast, the United States federal Civil Service has policies in place to offer recruitment and retention packages if a position is difficult to staff or if an employee expresses interest to move to a different department or leave the Federal service all together. Canada is also quite different from Australia as the APS experiences a large proportion of voluntary resignations from the service. In 2007-2008 the amount of separations was 12,176 with 8,785 being voluntary resignations. During that period only 1,935 employees retired. In 2008-2009 there were 10,460 separations of which 6,490 were voluntary resignations and only 1,691 employees retired. Resignations accounted for the greatest amount of separations from the Australian Public Service during both of those years (state of service data).
} 
Becker's side-bet theory of commitment could be still relevant, especially in the Canadian federal Public Service, as employees are committed to staying with their organization. Moreover, if the Canadian federal employees feel bounded to the federal Public Service because of the high cost of separation, the ease of intra-organizational mobility could enable them to achieve more desirable jobs and career progression, as per March and Simon's ease and desirability theory.

March and Simon's (1958) ease and desirability theory examines an employee's desire to move and the ability to do so. The theory outlines that when employees believe their efforts outweigh the rewards provided by their organization, their desirability to move will be greater than employees who believe their efforts are adequately rewarded. Moreover, the second aspect of the theory postulates that when there is an abundance of job vacancies, usually dependent on a country's economic status, the employees would be more likely to leave their job due to the ease of acquiring another job. However, it is the additive effect of the perceived ease of movement and the desirability of movement that predicts mobility.

Employees working within the federal Public Service are able to move easily based on the number of positions that are constantly available exclusively to public servants. Therefore, one of the conditions of the theory, ease of movement, is met. Moreover, it could be speculated that employees who have the necessary skills and backgrounds to meet job posting requirements, whose personal circumstances permit job moves, would have greater ease of movement. The second aspect of the theory, desirability, is assumed to have been met, as mobility occurs readily within the federal 
Public Service. However, what is currently missing in understanding this theory is what factors are associated with employees' desire to leave their department.

The voluntary intra-organizational mobility continues to rise within the Public Service of Canada (PSC, 2008). With existing internal opportunities and the ability to move easily, it is relatively easy for employees in the Public Service to be mobile. However, for the organization, it is usually difficult to staff new positions. It can take, on average, 6 months to staff a position (Macdonald, 2011), or in the best-case scenario, about 1.5 months (Macdonald, 2011). There is a substantial investment for the department due to the cost of hiring a new employee and the investment of time and resources in training new employees. Therefore, examining inter-departmental mobility and the factors associated with it is important for developing a pro-active approach and to contribute to the understanding of the desirability aspect of March and Simon's theory within a federal public service context.

\section{Predictors of Mobility}

This section summarizes job-related and organizational-level predictors of intraand inter-organizational mobility as well as demographic variables that have been related to these kinds of mobility. The most prevalent demographic predictors that have been noted for their relation to turnover and turnover intention are age (De Vos et al., 2008; Ito, 2003; Otto et al., 2010) and education (Ito, 2003; Tanova \& Holtom, 2008) whereby younger and more educated employees are more likely to leave.

Job-related predictors of mobility are the push and pull factors related to one's job that contribute to employees' decision-making regarding their intent to move or mobility. According to the intent to leave and turnover literature, job-related predictors 
push employees out of their current organization and into another (Ostroff \& Clark, 2001). Job-related predictors that have been shown to have an association with mobility intentions and actual mobility are: lack of a convenient work schedule (Millet et al 1990), salary, lack of challenge, lack of recognition, ineffective leadership, lack of teamwork (Ramlall, 2003), low job autonomy, low departmental resources, disengagement (De Lange et al., 2008), low job satisfaction, and a stressful work environment.

Organizational-level predictors are the push and pull factors that attract someone to an organization or strengthen their desire to leave an organization. Organizational-level predictors are related to organizations' policies, practises, culture, and structure (Ostroff \& Clark, 2001). Among the reported organizational-level predictors of employee mobility intentions and actual mobility are: organizational commitment, person-organization fit, career progression, career opportunities, and perceived organizational support (Cho, Johanson, \& Guchait, 2009; Curry, 2009; Ito, 2003; Kondratuk et al., 2004; Liu, Liu, \& Hu, 2010; Ramlall, 2003; Tett \& Meyer, 1993).

Predictors of intra-organizational mobility. Research on intra-organizational mobility has typically examined involuntary movements (upward, downward, or horizontal moves) within the same organization. This research has almost exclusively focused on either the impact that various types of moves had on employees (ArmstrongStassen, 2003; Kallenberg \& Mastekaasa, 2001), or employees' perceptions on making various types of intra-organizational moves (Beehr \& Taber, 1993; Donnelly, 2009; De Vos et al., 2008). None-the-less, there have been few studies that examined the predictors of voluntary movements within an organization and the demographic variables that partially impact the reasons and types of moves being made (Curry, 2009; Ito, 2003; Ito 
\& Brotheridge, 2005; Jackofsky \& Peters, 1983; Kondratuk, Hausdorf, Korabik, \& Rosin, 2004).

Jackofsky and Peters (1983) were among the first researchers to note that the reasons employees had for wanting to move internally were the same as the reasons employees moving externally had. Guided by March and Simon's (1958) ease and desirability theory, the authors found that the relationship between satisfaction and job turnover (intra-organizational mobility) and organizational turnover (inter-organizational mobility) was negative among individuals with greater perceived ease of movement. Integrating March and Simon's ease and desirability theory with Becker's side-bet theory of commitment, it could be speculated that, even though employees are bounded to their organization through making side-bets, they can still move internally without disrupting the side-bets they have made in relation to their organization. Other predictors of voluntary intra-organizational mobility explored in the literature include affective, continuance and normative commitment. Kondratuk, Hausdorf, Korabik, and Rosin (2004) found that affective, continuance, and normative commitment were all lower for internal movers than external movers before making a move compared to those who remained in their position (stayers).

Of the limited research available on predictors of intra-organizational mobility, two studies were conducted within the federal Public Service of Canada. Ito (2003) studied employees from various departments located in western Canada to examine mobility patterns and found that the majority of employees (75\%) looking for a new job were looking to move internally in the Public Service. It was found that the level of promotion stress and disappointment with regard to promotions can lead to voluntary turnover and 
reduced commitment, thus stressing the importance of employees' satisfaction with their career opportunities and commitment for their mobility intentions. Moreover, higher scores on commitment were related to a lower intention to search for alternative jobs.

Ito and Brotheridge (2005) studied Government of Canada employees working in the prairie region. The study revealed that affective commitment and dependence on the organization (similar to the concept of continuance commitment) were negatively associated with turnover intentions. Career adaptability was positively related to affective commitment and also positively related to turnover intentions. Moreover, supervisory career support was significantly and negatively related to intention to leave.

Based on the research outlined above, it appears that job satisfaction, organizational commitment, promotion stress, career development and opportunities, and supervisory career support are factors related to voluntary intra-organizational mobility. Job satisfaction, a stressful work environment, and supervisor support were examined in the current study as the job-related predictors of voluntary intra-organizational mobility. Organizational commitment and career development and opportunities were examined as the organizational-level predictors of voluntary intra-organizational mobility.

Research has shown that the likelihood of employees making intra-organizational movements and the type of movements made are partially explained by the demographic variables of age, education, and gender (De Vos, Dewettinck, \& Buyens, 2008; Ito, 2003: Otto et al., 2010; Valcour \& Tolbert, 2003). Research suggests that internal mobility is associated with higher earnings for both genders (Valcour \& Tolbert, 2003). Among the intra-organizational mobility literature, age was the predominant demographic factor explored for its negative association with one's intention to leave or change occupations 
(De Vos, Dewettinck, \& Buyens, 2008; Ito, 2003: Otto et al., 2010). Examining Canadian federal public servants, Ito (2003) noted that younger employees (age 26-35) were more likely to search for a new job within the Public Service, and that employees only holding a high school diploma were the least likely to search for a new position.

Therefore, it appears that employees who are younger and more educated are more likely to make an intra-organizational move. Aligned with this research and particularly with Ito's (2003) study in the Canadian federal government context, similar demographic patterns were expected in the current study, i.e., younger and more educated employees would be more likely to make an intra-organizational move within the federal Public Service of Canada.

Predictors of inter-organizational mobility. As limited research is available on the predictors of intra-organizational mobility, research examining the predictors of interorganizational mobility was also used to guide the current study. Inter-organizational mobility and intention to move have been studied extensively as turnover and turnover intention in various organizations worldwide (Griffeth, Hom, \& Gaertner, 2000; Koch \& Steers, 1978; Porter \& Steers, 1973; Porter, Steers, Mowday, \& Boulian, 1974; Mobley, 1977; Mobley, Horner, \& Hollingsworth, 1978; Tett \& Meyer, 1993). Job satisfaction and organizational commitment have been the most salient predictors identified in the literature (Cho, Johanson, \& Guchait, 2009; Kallenberg \& Mastekaasa, 2001; Kondratuk, Hausdorf, Korabik, \& Rosin, 2001; Liu et al., 2010; Murrell, Frieze, \& Olsen, 1996; Otto, Dette-Hagenmeyer, \& Dalbert, 2010; Tett \& Meyer, 1993). However, other factors that have shown negative associations with turnover intentions and actual mobility are one's supervisor, career development and progression, and person-organizational fit; whereas, 
emotional/physical strain and burnout have shown positive associations to turnover intentions (Griffeth, Hom, \& Gaertner, 2000; Liljegren \& Ekberg, 2009; Liu, Liu, \& Hu, 2010; Ng et al., 2007; Otto et al., 2010; Swaen, Kant, Van Amelswoort, \& Beursken, 2002).

Ramlall (2003) showed that salary, lack of challenge and opportunity, lack of career advancement opportunities, lack of recognition, ineffective leadership, and inadequate emphasis on teamwork propelled employees to leave their organization. Additionally, the National Centre for Vocational Educational Research in Australia supported relationships seen in Ramlall's research as it was suggested that "a lack of career development and support" was the primary reason for employees working for local government councils to leave, followed by "unsatisfactory work environments" (Curry, 2009). Cho, Johanson, and Guchait (2009) results on the indicators of intention to stay versus leave an organization suggest that perceived organization support was negatively related to turnover intentions.

Along similar lines, $\mathrm{Liu}, \mathrm{Liu}$, and $\mathrm{Hu}$ (2010) showed that person-organization fit had a strong negative association with turnover intention and that job satisfaction mediated the relationship between person-organization fit and turnover intention. Their study demonstrates the availability of research on the relationship between personorganizational fit and turnover intention, within a public service context, however, there fails to be research conducted on the association between person-job fit and voluntary intra-organizational mobility. This latter relationship was tested in the current study. It was expected that the negative association found between person-organization fit and 
turnover intention in the Chinese Public Service would be seen between person-job fit and one's intention to change departments in the federal Public Service of Canada.

It was interesting to note that Cho, Johanson, and Guchait (2009) found an unexpected positive relationship between perceived supervisor support and one's intention to leave. This finding may seem counterintuitive as it would appear that someone who has a positive relationship with their supervisor would be more likely to stay with their organization. However, if the supervisor support is reflected in career support and skill development, the employee progression may need to occur through inter- or intra- organizational movements. This is an interesting finding to keep in mind when exploring the relationship between perceived supervisor support and one's intention to change departments in the present study.

In summary, based on the above research, it was predicted that career development opportunities, job satisfaction, feedback, teamwork, and supervisor support would be associated with intentions to change departments. The demographic variables of age, gender, and education, examined in research pertaining to inter-organizational mobility show similar patterns to those explored in the intra-organizational mobility research. For example, age continues to show a negative relationship with one's intention to move and with actual turnover (Griffeth et al., 2000; Liljegren \& Ekberg, 2009: Liu, Liu, \& Hu, 2010; Miller, Powell, \& Seitzer, 1990; Ramlall, 2003), i.e., younger employees are more likely to turnover than older employees. Further, gender differences continue to be seen in the inter-organizational research. Gender was found to influence the likelihood of making an inter-organizational move as women made more external moves than did men (Valcour \& Tolbert, 2003). Employees with higher levels of 
education were likely to have better labour-market alternatives leading to higher mobility (Tanova \& Holtom, 2008). Moreover, Ito (2003) found in the federal Public Service of Canada that more educated employees were more likely to search for jobs in the private sector, therefore intending to make an inter-organizational move. With insight from the above reported studies, it was expected that age and education would be related to one's intention to change departments. Gender was not examined as a demographic predictor of intention to change departments as research has predominantly examined gender differences with respect to turnover and there is no research to suggest that it would impact intra-organizational mobility.

In summary, in view of the lack of research on the job-related and organizationallevel predictors that are associated with intent for voluntary intra-organizational mobility within a federal government context, research on both inter- and intra-organizational mobility in both the private and public sectors was reviewed to guide the hypotheses for the current study. Although some research has been conducted by the federal government in various countries, it has typically focused on rates as opposed to the predictors of the employee movement. Therefore, it was expected that the present study would help fill the gap in the intra-organizational mobility research by identifying job-related and organizational-level predictors of intention to change departments within the federal Public Service of Canada.

\section{Current Study Research Questions and Hypotheses}

The aim of the present study was to identify the job-related and organizationallevel predictors of voluntary intra-organizational mobility in the Public Service of Canada by exploring Canadian federal public servants' intention to change departments. 
As research on turnover has shown, intent is the current best predictor of actual departures and the proxy measure most widely used (Griffeth et al., 2000). Intention to change departments is a variable that divides employees into those who plan on staying with or leaving their department or agency for a job in another department/agency within the next 2 years. As the mobility statistics for the Canadian Public Service identify internal mobility as the mobility with the highest rate, the current study is focused on examining intent to move between departments. Based on the reviewed mobility research, it was expected that the reasons for employees' deciding to move within the federal Public Service would be aligned with both inter- and intra-organizational mobility research, although technically employees are making an intra-organizational move. This is due to the fact that the majority of the intra-organizational mobility research examines involuntary moves and the impact those moves have on job and organizational factors. Therefore, as government employees are making voluntary moves the factors that drive those moves are expected to be consistent with both the limited voluntary intraorganizational mobility research and the findings from the inter-organizational mobility research.

Guided by the findings of the reviewed literature, the following demographic, job, and organizational variables were examined as predictors of intention to change departments: (a) age bands, (b) education, (c) person-job fit, (d) job satisfaction, (e) performance feedback, (f) teamwork, (g) stressful work environment, (h) supervisor support, (i) organizational commitment, and (j) career development and opportunities. Stemming from the findings on mobility reported in the literature and discussed above, 
the hypotheses in the present study involved direct, mediated, and moderated relationships. These relations are graphically depicted in the model below.

Figure 1: Conceptual Model of Intra-Organizational Mobility

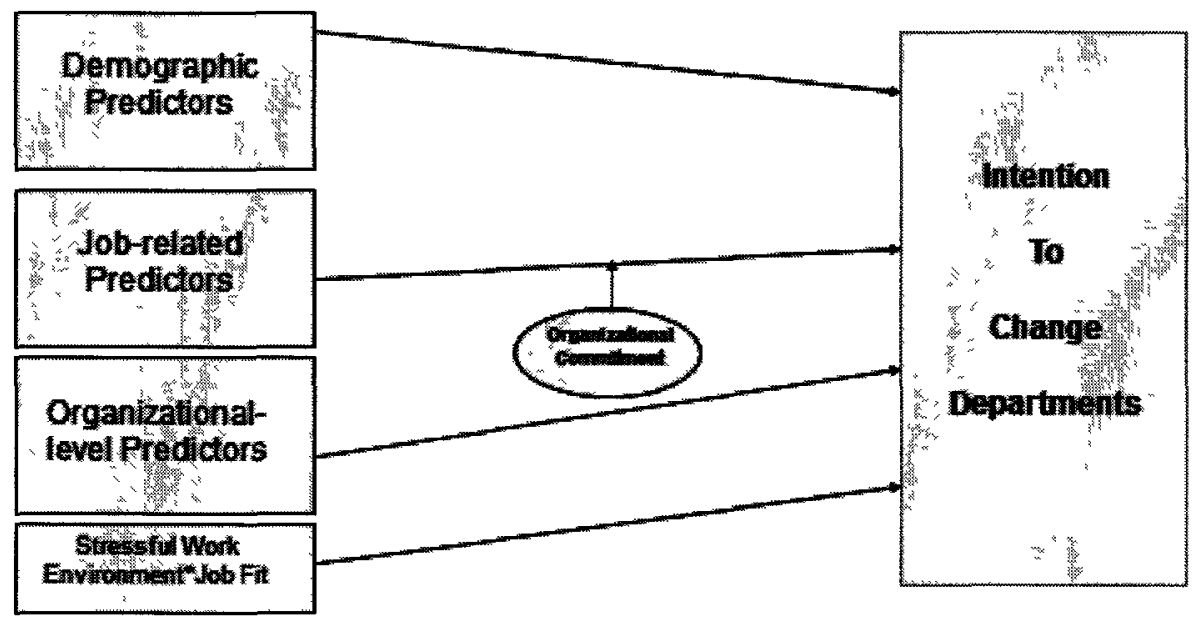

In line with previous research, it was hypothesized that the demographic variables of age (grouped into age bands ${ }^{5}$ ) and education ${ }^{6}$ would be significantly associated with employees' intention to change departments, such that younger employees would be more likely to intend to change departments than their older counterparts. It was also hypothesized that the more educated employees would be more likely to intend to change departments than their less educated counterparts.

\footnotetext{
${ }^{5}$ The age bands used in the current study were the following: Older (age 45 to 59), Middle (age 30 to 44 ), and Youngest (29 years of age and younger).

${ }^{6}$ Education categories were the following: high school graduates (and below), college/university below Bachelor's degree, and university degree.
} 
Based on the reviewed literature, it was expected that the job-related predictors of person-job fit, job satisfaction, performance feedback, and teamwork would have a negative association with one's intention to change departments within the next two years. It was also expected that a stressful work environment and supervisor support would have a positive association with one's intention to change departments within the next two years. It was hypothesized that job satisfaction would be the most salient jobrelated predictor. To elucidate the association of the job-related predictors with one's intention to change departments when accounting for the demographic characteristics, age (age bands) and education were entered into a sequential logistic regression model with the job-related factors that showed significance in the initial model.

Further, it was expected that organizational commitment would have a negative association with employees' intention to change departments within the next two years. It was also expected that career development and opportunities would have a negative relationship with employees' intention to change departments within the next two years. Moreover, it was hypothesized that organizational commitment would be the most salient organizational-level predictor. The demographic variables of age (age bands) and education were used in a follow up analyses to elucidate the association of the significant organizational factors to one's intention to change departments when accounting for the characteristics of age (age bands) and education.

The final model of intention to change departments in the federal Public Service, examined demographic characteristics, job-related predictors, and organizational-level predictors using a sequential logistic regression model. The final model was used to test the hypothesis that all of the job-related and organizational-level predictors would work 
in an additive fashion contributing unique variance to the outcome measure of intention to change departments above and beyond the demographic factors.

The distinction between moderators and mediators in the present study is drawn from Baron and Kenny's (1986) article whereby they clearly distinguish between the two. The mediator that was chosen was organizational commitment because theory has shown that it is related to job satisfaction, and is also strongly related to turnover intention (i.e., those with low levels of organizational commitment are likely to have higher levels of turnover intention) (Tett \& Meyer, 1993). Therefore, the mediational hypothesis that was tested in this study consisted of the following elements: (1) employees who have high levels of job satisfaction would have a lower likelihood of intending to change departments (path c); (2) those with high levels of job satisfaction would have high levels of organizational commitment (path a); and (3) employees who have high levels of organizational commitment would also have a lower likelihood of intending to change departments (path b). Finally, once the relationship between organizational commitment and intention to change departments was accounted for, there would be a weaker relationship between job satisfaction and intention to change departments (path c'). 
Figure 2: Mediation Hypothesis

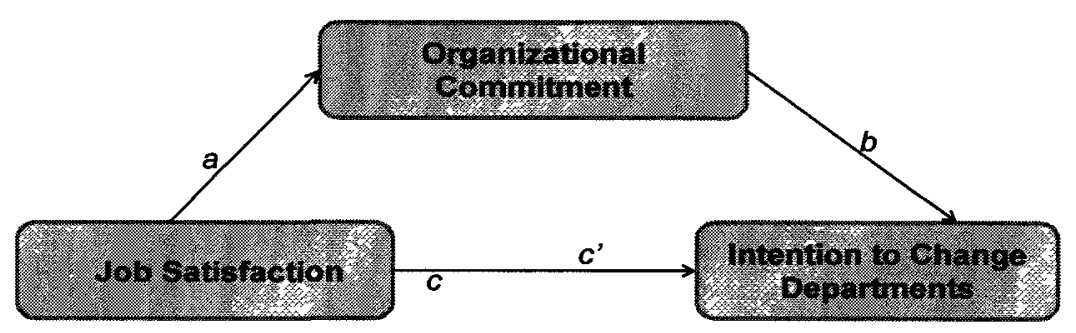

To test whether the indirect effect was significant, the statistical software program STATA was used for its ability to generate bootstrapping estimates and confidence intervals for the indirect effect. Therefore, organizational commitment was hypothesized to be a partial mediator, whereby those individuals who are high in job satisfaction would have high levels of organizational commitment which subsequently would be associated with a lower likelihood of intending to change departments.

In line with previous research, one moderated relationship was also hypothesized. A buffering effect of person-job fit was hypothesized, i.e., person-job fit would interact with stressful work environment in its association with one's intention to change departments. This interaction is expected to be seen as employees may be less likely to intend to leave their current position if they perceive their job to be a good fit with their skills and interests, even if they are working in stressful conditions. 
The job-related predictors that were examined in the current study for their relation to intention to change departments are defined as follows: person-job fit is defined as the match between the individuals' skills/abilities and the demands of the position they are in (ADBM, 2006). Job satisfaction generally refers to employees' affective and cognitive appraisals about their job (how much employees likes their job) (Hausknecht, Hiller, \& Vance, 2008) (e.g., co-workers, supervisor, work demands). Performance feedback is a review of one's performance given by a direct manager to note if expectations are being met/exceeded, and to provide guidance for the future. Teamwork refers to employees who work with a work unit on a task or tasks. Employees, who have cohesive work groups that value teamwork and have a sense of togetherness, generally are expected to rate their work experience as better than those who have poor team support. An immediate supervisor refers to the individual that provides the employees with tasks and feedback regarding their work. Supervisor support is defined as the employees' perception of the support they receive from their immediate supervisor.

The organizational factors that were examined in the current study are defined as follows: career development and opportunities refers to employees' perception that their organization has opportunities for promotion/skills development. Career development and opportunities also includes an organization's commitment to ensuring that employees have the tools available to develop as professionals. Organizational commitment can be broadly defined as employees' attachment to their organization. 


\section{Method}

\section{Sample}

The federal Public Service of Canada has a population of approximately 260,000 employees, working in various departments with varying demographic profiles, throughout Canada. In 2008, the Public Service Employee Survey (PSES) was sent to 257,764 employees, which was everyone that was working for the federal Public Service in November of 2008 . The response rate was $65.8 \%$, for a final sample of 169,680 . For the present study, a stratified random sample of the population was derived, using age bands ${ }^{7}$ and education as stratification variables, which divided the sample into nine strata, shown in Appendix A. The employees who were in the "Oldest" age band (60+) were excluded from the sampling procedure as there were only 80 employees in the Public Service $(N=169,680)$ who were $60+$ and reported intentions to change departments. This represented $.68 \%$ of the overall number of employees in the Public Service who intended to change departments $(\mathrm{N}=12,995)$. As the portion of these employees was too small to ensure a sufficient amount of leavers and stayers in each educational category of the sample for the current study, the employees who were in the "Oldest" age band were not included in the sampling procedure and therefore filtered out of the study.

To ensure representativeness and sufficient sample size, 1,350 respondents were randomly drawn from the population for each combination of the two demographic variables. The number of respondents chosen for each stratum was selected based on the stratum that had the smallest number of employees. The Youngest and high school

\footnotetext{
${ }^{7}$ The age of respondents was a categorical variable in the survey thus making it impossible to describe the age range of respondents. Since the distribution of respondents into age categories resembled the distribution of respondents into age bands, the latter based on age ranges as well, and because of the smaller number of age bands than age groups, the age bands were used in the stratification of the sample to distinguish between younger and older employees.
} 
educated had 1,448 employees and so 1,350 was selected to allow for random selection. This resulted in a final sample of 12,150 . Because this is a large sample, in addition to the obtained significance levels, a criterion of meaningfulness was introduced whereby significance was set at the $p=.01$ level and at least $2 \%$ of the variance explained in the dependent variable was needed to deem the findings meaningful. The established criterion of meaningfulness is to ensure that when results are statistically significant they are also practically significant (Dobreva-Martinova, Villeneuve, Matheson, \& Strickland, 2002).

The sample for the current study was composed of $39.3 \%$ males $(n=4,781), 59.6$ $\%$ females $(n=7,245)$ and $1 \%$ not stated $(n=124)$. The sample consisted of indeterminate employees (permanent workers who are not casual, student, seasonal nor term employees), almost all of whom worked full-time $(n=11,865,97.7 \%)$. There were 263 part-time employees (2.2\%) and 22 employees who did not state their employment status (.2\%). There were 7,928 (65.3\%) employees who reported English as their first official language, 4,201 employees (34.6\%) who reported French as their first official language and $21(.2 \%)$ employees who did not respond to the question. Due to sampling techniques, there was an even split between respondents who had high school education ( $n=4,050,33.3 \%)$, college or university (below a Bachelor's degree) education ( $n=$ $4,050,33.3 \%)$, and university education with a Bachelor's degree and above $(n=4,050$, 33.3\%). Due to sampling techniques there was an even distribution of respondents' age bands. The age bands used in this study were comprised of age cohorts; Youngest represented employees under the age of 30, Middle represented employees between the ages of 30 and 44, and Older represented employees between the ages of 45 and 59 . The 
Oldest employees, 60 years of age and older, were excluded from the study as the majority of their planned movements were for retirement $(\mathrm{N}=2053,89 \%)$. Therefore, the sample was comprised of Youngest $(n=4,050,33.3 \%)$, Middle $(n=4,050,33.3 \%)$ and Older $(n=4,050,33.3 \%)$ age bands.

\section{Procedure}

Data collection. The Treasury Board of Canada Secretariat was responsible for the development of the survey. Statistics Canada conducted focus group testing of the survey questions and was responsible for the data collection. Statistics Canada houses and safeguards the survey data. The Chief Statistician at Statistics Canada signed off on the survey before its administration. The survey was approved for administration by the senior levels across departments and central agencies within the federal Public Service of Canada, and endorsed by Statistics Canada.

The PSES 2008 was administered from November 3rd, 2008 to January 9th, 2009 in both official languages (English and French). Employees received a unique password to use to access the survey. Employees received a weekly reminder to participate in the survey. In situations where employees did not have access to the internet, a paper and pencil copy of the survey was provided. Respondents were not required to provide their name or any other identifier, as it was an anonymous survey. Participants were informed that the survey was voluntary, that it would take approximately twenty to thirty minutes to complete, and were assured of the confidentiality of their responses.

Data Access. The data collected for the Public Service Employee Survey (2008) are housed at Statistics Canada and the researcher gained access to the data through becoming a deemed member of Statistics Canada by taking the "Oath or Affirmation of 
Office and Secretary" from the Statistics Act promising to protect confidentiality. The data access is granted through the Research Data Centre (RDC) division of Statistics Canada. The data kept at the RDC is protected under the Statistics Act. There are a few limitations with respect to using Statistics Canada data including access to the data and disclosure procedures. The data are only available during weekdays and each output generated has to be vetted for release. Therefore, if any cell in the analysis is less than fifteen unweighted cases or five weighted cases, the data will not be released due to protecting the anonymity of the individuals who participated in the survey. A large sample size has been selected for this study to ensure cell counts greater than fifteen and to aid in the release of the data.

\section{Measures}

Starting with the outcome variable, this section describes the measures that were used in the PSES 2008. Despite the availability of well used and validated scales to measure job and organizational constructs, internal scales were developed by working groups to suit the operational requirements of the federal Public Service. Consultation took place with various stakeholders and bargaining agents to ensure a measure that captured a wide range of factors specific to the federal Public Service. The first PSES was administered in 1999. Many items have been kept throughout the years for continuity, trend analysis and to assess organizational needs. Moreover, the factors measured in the PSES have been recently used as performance measures in the people management domain. Although the PSES scales can be described in terms of common organizational constructs (e.g., job satisfaction), the items were developed internally and were not borrowed from pre-existing measures. Age bands, education, person-job fit, job 
satisfaction, performance feedback, teamwork, stressful work environment, supervisor support, organizational commitment, and career development and opportunities were considered as predictors of intention to leave one's department to pursue a job in another department/agency. See Appendix B for the full set of measures.

Intention to change departments. The outcome variable, intention to change departments, was assessed with two questions that measured employees' intent to leave their department or agency to pursue a position in another department or agency. The first question, "Do you intend to leave your department or agency in the next two years?" had three categorical response options: "Yes", "No", "Not Sure". Employees who responded "Yes" were further asked to provide their reason for leaving through four response options: 1) to retire, 2) to pursue a job in another department or agency, 3) to pursue a job outside the federal Public Service, or 4) other. The resulting outcome variable was composed of 2 groups: (1) stayers (who answered "No" or "Not sure" to the first question), and (2) leavers (who answered "Yes" to the first question and selected "to pursue a job in another department or agency" as a response to the second question.

Age Bands. Age groups were measured using one item: "What is your age group?" The response options were: a) Up to 24 years, b) 25 to 29 years, c) 30 to 34 years, d) 35 to 39 years, e) 40 to 44 years, f) 45 to 49 years, g) 50 to 54 years, h) 55 to 59 years, and i) 60 years and over. These nine age groups were combined into four age bands: Youngest ( $<30$ years), Middle (30-44 years), Older (45-59 years), and Oldest (60+ years). The study only examined Youngest, Middle, and Older. Age bands were dummy coded with Older (45-59) as the reference group ( 00 ) followed by Youngest $(<30)$ as AgeBand1 (1 0) and Middle (30-44) as AgeBand2 (0 1). 
Education. Education was measured using one item: "What is the highest level of education you have ever completed?" There were five response options including: a) secondary/high school graduation certificate or equivalent or less, b) diploma or certificate from a community college, CEGEP, institute of technology, nursing school, etc. or a trades certificate or diploma, c) university certificate or diploma below the bachelor's level, d) Bachelor's degree (e.g., BA, BSc), and e) university certificate or diploma above the bachelor's level including Master's degree (e.g., MA, MSc, MEd) or professional degree (e.g., LLB, degree in medicine, dentistry, veterinary medicine or optometry [MD, DDS, DMD, DVM, OD]) or earned doctorate (e.g., PhD, DSc, DEd). These five categories were combined into the following three education groups: high school, college/university below Bachelor's degree, and Bachelor's degree and above. Education was dummy coded with high school educated as the reference group $\left(\begin{array}{ll}0 & 0\end{array}\right)$ followed by college/university below Bachelor' degrees as Ed1 (1 0) and Bachelor's degree and above as $\operatorname{Ed} 2\left(\begin{array}{ll}0 & 1\end{array}\right)$.

Person-job fit. Person-job fit was measured using two items: "My job is a good fit with my interests" and "My job is a good fit with my skills." These items were rated on 5-point Likert scales ranging from strongly agree to strongly disagree with a Cronbach's alpha coefficient of .78. The two items were correlated at $r=.64$. Generally a Cronbach's alpha of .70 and above is deemed acceptable (Nunnally, 1978).

Job satisfaction. Job satisfaction was measured using the following four items: "I get a sense of satisfaction from my work", "Overall I like my job", "I am satisfied with my current work arrangements (e.g., regular work hours, telework, compressed work week)", and "I am satisfied with my department/agency." All items were rated on 5-point 
Likert scales ranging from strongly agree to strongly disagree and had a Cronbach's alpha reliability coefficient of .75 . Inter-item correlations ranged from $r=.37$ to $r=.81$.

Performance feedback. Performance feedback was measured using four items, for example, "My immediate supervisor assesses my work against identified goals and objectives" and "I receive meaningful recognition from my immediate supervisor when I do a good job." All the performance feedback items were assessed using 5-point Likert scales ranging from strongly agree to strongly disagree and had a Cronbach's alpha reliability coefficient for the scale was .88 , with inter-item correlations ranging from $r$ $=.62$ to $r=.72$.

Teamwork. Teamwork was measured using four items such as "In my work unit, we work cooperatively as a team" and "In my work unit, I believe that we hire people who can do the job." The four items were measured on 5-point Likert scales ranging from strongly agree to strongly disagree and had a Cronbach's alpha of .71. Inter-item correlations ranged from $r=.32$ to $r=.43$.

Stressful work environment. Stressful work environment was measured using six items, for example "I feel that the quality of my work suffers because of constantly changing priorities" and "I feel that the quality of my work suffers because of unreasonable deadlines." All six items were rated on 5-point Likert type scales ranging from strongly agree to strongly disagree with a Cronbach's alpha of .85. Inter-item correlations ranged from $r=.40$ to $r=.59$.

Supervisor support. Supervisor support was measured using the following three items: "My immediate supervisor keeps me informed about the issues affecting my work", "I can count on my immediate supervisor to keep his or her promises", and "If I 
were to suggest ways to improve how we do things, my immediate supervisor would take them seriously." All items were rated on 5-point Likert scales ranging from strongly agree to strongly disagree and had a Cronbach's alpha reliability coefficient of .88 . Interitem correlations ranged from $r=.67$ to $r=.77$.

Organizational commitment. Organizational commitment was measured using the following three items: "I would prefer to remain with my department or agency, even if a comparable job was available elsewhere in the federal Public Service", "I would prefer to remain with my work unit, even if a comparable job was available elsewhere in my department or agency", and "Based on my experience working in my department or agency, I would recommend it as a good place to work." The items were assessed on 5point Likert scales ranging from strong agree to strongly disagree and had a Cronbach's alpha reliability coefficient of .84 . Inter-item correlations ranged from $r=.39$ to $r=.69$.

Career development and opportunities. Career development and opportunities were measured using four items. The following are examples of items measuring this construct: "I have opportunities to develop and apply the skills I need to enhance my career", and "My department or agency does a good job of supporting employee career development." All of the items were rated on 5-point Likert scales ranging from strongly agree to strongly disagree and had a Cronbach's alpha reliability coefficient of .83 . Interitem correlations ranged from $r=.40$ to $r=.70$.

\footnotetext{
${ }^{8}$ This item in the organizational commitment scale may be reflective of turnover intentions, however as the study is archival, the scale was kept intact with the three items.
} 


\section{Results}

\section{Preliminary Analyses}

Data screening. Survey responses were initially screened for out of range values, patterns of responses, missing values, and univariate and multivariate outliers. The responses were examined for data entry/syntax errors by examining the range of each item and each scale. All values fell within the plausible range.

To examine the possibility of response bias, new variables were created to count the number of responses in each of the response categories. Examining the 5 new "count" variables, there were 15 respondent cases that selected the same response for 29 or 30 out of the 30 items that comprise the predictor variables. There was 1 case that selected the response of 1 (strongly disagree), 4 cases that selected the response of 3 (neither agree nor disagree), 4 cases that selected 4 (somewhat agree), and 6 cases that selected 5 (strongly agree) for 29 or 30 out of the 30 items used to create the predictor variables. These cases were further examined for the specific demographic variables of age bands and education, and for the outcome variable (intent vs. no intent to change departments). No pattern appeared for any of the examined variables. As these cases were showing response bias, they were deleted from the dataset. The remaining sample consisted of 12,135 respondents.

Missing values analysis. Missing values were first assessed at the case level, by creating another "count" variable that summed the number of missing responses out of the 30 items used for the scales, the outcome measure, and the 2 demographic items (age bands and education). The data set was sorted "descending" to highlight the cases that had a large amount of missing data. There were 20 cases that had 25 or more of the 33 
items missing $(76 \%)$ and therefore were removed from the sample, which left a sample of 12,115 .

A missing value analysis was then conducted to determine whether there was a problem with the pattern of missing data either at the variable level or at the case level. A filter variable was created to ensure the respondents who indicated intention to leave their job to retire, to pursue a job outside the public service, or for other reasons were filtered out before the missing value analysis was run therefore excluding 680 cases $^{9}$. These cases were filtered out of subsequent analyses and therefore not included in the missing values analysis to ensure validity of the test. Person-job fit had 3 missing cases $(<.1 \%)$, job satisfaction had 1 missing case (<.1\%), performance feedback had 28 missing cases (.2\%), teamwork had 3 missing cases (<.1\%), stressful work environment had 111 missing cases (1.0\%), supervisor support had 34 missing cases (.3\%), organizational commitment had 7 missing cases (.1\%), career development and opportunities had 11 missing cases (.1\%), age bands, education, and intent to change departments each had no missing data. The missing data in each variable was assessed and the data were analyzed using the omnibus Little MCAR test. A significant relationship was found for the variables $\left(x^{2}=125.3, d f=95, p=0.02\right)$. Although the MCAR test was significant at the 0.05 alpha level, a significant MCAR test when the missing data is ignorable can be due to double sampling (Schafer, 2007). As this study used a double sampling technique whereby two questions were used to form the dependent variable and generally researchers interpret MCAR as significant below the 0.01 alpha level, the missing data were interpreted to be missing completely at random.

\footnotetext{
${ }^{9}$ It is worth noting that only a very small portion of respondents indicated their intention to leave in order to pursue a job outside the federal Public Service [1.7\% (PSES 2008 sample) $1.6 \%$ (study sample) ]
} 
Based on a paper by Allison (2000), listwise deletion was selected as the method of choice for tackling the missing data. This method was chosen as there was less than $5 \%$ missing data overall, the removal of the cases would not impact power concerns for the current study, and listwise deletion is recommended when the data are missing completely at random.

Outliers. Tests for univariate and multivariate outliers were conducted. Univariate outliers were identified through the calculations of z-scores for each variable. There were no extreme high values that had Z-scores greater than 2.58; however, there were six variables that had extreme low values at both $-2 \mathrm{SD}(-2.58)$ and $-3 \mathrm{SD}(-3.29)$. Person-job fit had 330 extreme low values (163 at -2SD, 167 at -3SD), job satisfaction has 225 extreme low values (208 at - 2SD, 17 at $-3 \mathrm{SD})$, teamwork had 239 extreme low values (185 at -2SD, 54 at -3SD), performance feedback had 242 extreme low values at 2SD, supervisor support had 280 extreme low values at $-2 \mathrm{SD}$, and organizational commitment had 237 extreme low values at -2SD. It is expected that in a large dataset there would be cases that would fall into the extreme ends of the distribution (Cohen, Cohen, \& West 2003). Therefore, all cases were retained in the dataset.

When examining multivariate outliers, Mahalanobis Distance was computed and compared to the chi-square critical value $\left(d f=10, \alpha=0.001, x^{2}=29.59\right)$. Seventy-four multivariate outliers were present. The data were dummy coded and divided into groups of values exceeding the cut-off score $(1=$ multivariate outlier $)$ and values below the score $(0=$ other cases $)$. An independent t-test was performed on the grouping variable that divided the data into multivariate outliers and other cases to note differences in the demographic variables; no significant differences were found. To further ensure that the 
cases that were multivariate outliers were not significantly different from the other cases in the sample, the data were split using "intention to change departments" as the grouping variable and the independent t-test analysis was performed again on the outliers vs. other cases groups. There were no significant differences between the groups of the multivariate outliers and the other cases on any of the demographic variables for the stayers. There was, however, a significant difference between the multivariate outliers and the other cases on the demographic variable of "age bands" for the leavers. As it is expected that every large sample would contain some multivariate outliers and because fewer than $1 \%$ of the data in the present sample were outliers, the multivariate outliers were retained for this study. Therefore, the final sample had 11,412 respondents, of whom 1,107 (9.7\%) were leavers (intended to change departments) and 10,305 (90.3\%) were stayers (intended to stay with department).

Descriptive and correlational analyses. A correlational analysis was conducted to note associations between the independent variables as well as the association between each independent variable and the outcome variable. An initial analysis between the jobrelated predictors (person-job fit, job satisfaction, teamwork, performance feedback, stressful work environment and supervisor support), the organizational-level predictors (organizational commitment, career development and opportunities) and the outcome variable (intention to change departments) suggested multicollinearity between the variables of performance feedback and supervisor support, $r=.84, p<.001$. As the two predictors were so highly correlated, it was decided to combine the variables and keep the "supervisor support" title as it reflects both constructs. This new scale combined the three items from the performance feedback scale and the four items from the original 
supervisor support scale. A reliability analysis was performed on the new supervisor support variable and the analysis revealed the scale had a Cronbach's alpha of $\alpha=.93$ which improved from the previous "supervisor support" alpha of $\alpha=.88$. The range of inter-item correlations was between $r=.61$ and $r=.74$. A second correlational analysis was performed with the new supervisor support variable replacing the old supervisor support and performance feedback predictors (See Table 1). Descriptive information, including means, standard deviations and scale reliabilities, is provided in Table 1. 
Table 1.

Correlations, Means, Standard Deviations, and Reliabilities for Study Variables

\begin{tabular}{|c|c|c|c|c|c|c|c|c|}
\hline & $\begin{array}{l}\text { Intention to } \\
\text { Change } \\
\text { Departments }\end{array}$ & $\begin{array}{l}\text { Person- } \\
\text { Job Fit }\end{array}$ & $\begin{array}{c}\text { Job } \\
\text { Satisfaction }\end{array}$ & Teamwork & $\begin{array}{c}\text { Stressful } \\
\text { Work } \\
\text { Environment }\end{array}$ & $\begin{array}{l}\text { Supervisor } \\
\text { Support }\end{array}$ & $\begin{array}{c}\text { Organizational } \\
\text { Commitment }\end{array}$ & $\begin{array}{c}\text { Career } \\
\text { Development } \\
\& \\
\text { Opportunities } \\
\end{array}$ \\
\hline Person-Job Fit & $-.24 * * *$ & $(.78)^{b}$ & & & & & & \\
\hline Job Satisfaction & $-.31 * * *$ & $.64 * * *$ & $(.75)$ & & & & & \\
\hline Teamwork & $-.17^{* * *}$ & $.33 * * *$ & $.56 * * *$ & $(.71)$ & & & & \\
\hline $\begin{array}{l}\text { Stressful Work } \\
\text { Environment }\end{array}$ & $.13 * * *$ & $-.13 * * *$ & $-.37 * * *$ & $-.38 * * *$ & $(.85)$ & & & \\
\hline $\begin{array}{l}\text { Supervisor } \\
\text { Support }\end{array}$ & $-.20 * * *$ & $32 * * *$ & $.54 * * *$ & $.61 * * *$ & $-.32 * * *$ & (.93) & & \\
\hline $\begin{array}{l}\text { Organizational } \\
\text { Commitment }\end{array}$ & $-.39 * * *$ & $47 * * *$ & $.74 * * *$ & $.59 * * *$ & $-.37 * * *$ & $.56 * * *$ & $(.84)$ & \\
\hline $\begin{array}{l}\text { Career } \\
\text { Development \& } \\
\text { Opportunities }\end{array}$ & $-.17^{* * * *}$ & $.40 * * *$ & $.58 * * *$ & $.51 * * *$ & $-.33 * * *$ & $.53 * * *$ & $.54 * * *$ & $(.83)$ \\
\hline $\begin{array}{l}\mathrm{M} \\
\mathrm{SD}\end{array}$ & & $\begin{array}{l}8.13 \\
1.81\end{array}$ & $\begin{array}{c}16.07 \\
3.30\end{array}$ & $\begin{array}{c}15.65 \\
3.21\end{array}$ & $\begin{array}{c}18.35 \\
5.36\end{array}$ & $\begin{array}{c}26.89 \\
7.08\end{array}$ & $\begin{array}{l}11.18 \\
3.12\end{array}$ & $\begin{array}{c}14.00 \\
4.07\end{array}$ \\
\hline
\end{tabular}

${ }^{\mathrm{a}}$ Intent to change departments: $0=$ stayers; 1 = leavers

${ }^{b}$ Reliabilities are listed in the diagonal

${ }^{* *} p<.01, * * * p<.001$ 
The correlational analysis suggested the following predictors had a negative association with one's intention to change departments; person-job fit, job satisfaction, teamwork, supervisor support, organizational commitment, and career development and opportunities. Therefore as person-job fit, job satisfaction, teamwork, supervisor support, organizational commitment, and career development and opportunities decrease, employees' intention to change departments increase. Stressful work environment had a positive relationship with intention to change departments such that the more employees' perceive their work environment as stressful the more they would intend to leave their department to pursue an opportunity in another department.

\section{Main Analyses}

Due to the dichotomous nature of the dependent variable, logistic regression analyses were used to test the main hypotheses in this study. Although logistic regression makes no assumptions regarding the distribution of the sample, a few assumptions are still made that improve the efficiency and power of the analysis; therefore, the data were examined to assess whether the assumptions of multivariate normality, linearity in the logit, independence of errors, and the absence of multicollinearity were met. Multivariate normality, independence, and absence of multicollinearity were met; however, linearity in the logit failed to be met for career development and opportunities. As the study did not aim to classify individuals, the analyses were run without transformations. Further description of assumption testing is provided in Appendix C.

Demographic predictors of intention to change departments. A direct logistic regression analysis was performed using the ENTER method. The logistic regression was 
performed on intention to change departments as the outcome variable, with age bands and education (grouped) as the demographic predictors. Age bands was included as a categorical predictor variable; it was dummy coded by creating two grouping variables (Youngest \& Middle) and a reference group (Older). The two grouping variables were examined in relation to the Older reference group to test the hypothesis that younger employees are more likely to leave their department to pursue an opportunity in another department/agency than older employees. Education was included as a second categorical predictor; it was dummy coded by creating two grouping variables (college/university below Bachelor's, and Bachelor's degree and above) and a reference group. The high school group was used as the reference group as it was hypothesized that those with more education would be more likely to intend to change departments. The other two education groups were examined in relation to the high school reference group. Intention to change departments was coded as follows: $0=$ stayers and $1=$ leavers.

A test of the full model with the 2 demographic predictors against a constant only model was statistically significant, $\chi^{2}(4, N=11,412)=156.63, p<.001$, indicating that the predictors reliably distinguished between those respondents who intended to stay and those who intended to leave their department for other internal opportunities.

Nevertheless, Nagelkerke's $\mathrm{R}^{2}$, a test statistic that measures the proportion of variance the model is accounting for, was weak (Nagelkerke's $R^{2}=.03$ ) indicating that there was a substantial amount of variance unaccounted for in the model. Three of the four demographic variables significantly contributed to the ability of the model to predict those employees who planned on changing departments. Table 2 shows the regression coefficients, Wald statistics, odds ratios, and $95 \%$ confidence intervals for the odds ratios 
for each of the demographic predictors. The Wald statistic obtained for Age Band ${ }_{(1)}$ (difference between Older and Youngest) (Wald $\left.\chi^{2}=124.12, p<.001\right)$, Age Band $(2)$ (difference between Older and Middle) (Wald $\chi^{2}=51.74, p<.001$ ), and Education $(2)$ (difference between high school education and Bachelor's+ education ) (Wald $\chi^{2}=17.22$, $p<.001$ ), all showed to be significant predictors of intent to leave one's department to pursue an opportunity in another department. Education ${ }_{(1)}$ (difference between high school education and college/university below Bachelor's education) (Wald $\chi^{2}=.32, p>$. 05) failed to show significance.

Table 2 .

Direct Logistic Regression: Demographic Factors and Intention to Change Departments

\begin{tabular}{|c|c|c|c|c|c|c|}
\hline \multirow[b]{2}{*}{ Variable } & \multirow[b]{2}{*}{$\mathrm{B}$} & \multirow[b]{2}{*}{ S.E. } & \multirow[b]{2}{*}{ Wald Test } & \multirow{2}{*}{$\begin{array}{l}\text { Odds } \\
\text { ratio }\end{array}$} & \multicolumn{2}{|c|}{$95 \%$ C.I. } \\
\hline & & & & & Lower & Upper \\
\hline Age Band & & & $124.37 * * *$ & & & \\
\hline AgeBand $_{1}$ (Older vs. Youngest) & .97 & .09 & $124.12 * * *$ & 2.64 & 2.23 & 3.13 \\
\hline AgeBand $_{2}$ (Older vs. Middle) & .65 & .09 & $51.74 * * *$ & 1.92 & 1.61 & 2.29 \\
\hline Education & & & $21.06 * * *$ & & & \\
\hline \multicolumn{7}{|l|}{ Education $_{1}$ (High School vs. } \\
\hline \multicolumn{7}{|l|}{ College/University below } \\
\hline Bachelor's) & .05 & .08 & .32 & 1.05 & .89 & 1.23 \\
\hline \multicolumn{7}{|l|}{ Education $_{2}$ (High School vs. } \\
\hline Bachelor's+) & .32 & .08 & $17.22 * * *$ & 1.38 & 1.19 & 1.60 \\
\hline Constant & -2.98 & .09 & $1135.85^{* * *}$ & .05 & & \\
\hline
\end{tabular}

$* * *=p<.001 * *=p<.01$ 
The odds ratios obtained for this model indicate that when compared to the Older age band, employees belonging to the Youngest age band had a 2.64 times greater likelihood of reporting intention to change departments, $O . R .=2.64,95 \% \mathrm{CI}[2.23$, 3.13]. In reference to the Older age band, employees in the Middle age band were 1.92 times more likely to intend to change departments, $O . R .=1.92,95 \% C I[1.61,2.23]$. Moreover, the odds of intending to change departments increased by $38 \%$ for those with Bachelor's degree or higher education when compared to those with a high school education, $O . R .=1.38,95 \% C I[1.19,1.60]$.

Job-related predictors of intention to change departments. A direct logistic regression analysis was performed on the job-related predictors using the ENTER method. The logistic regression was performed on intention to change departments as the outcome with person-job fit, job satisfaction, teamwork, stressful work environment, and supervisor support as the predictor variables. Intention to change departments was coded as follows: $0=$ stayers (plan to stay in one's department) and $1=$ leavers (plan on changing departments). In the absence of previous research, the results of this analysis would be used to establish the significant job-related predictors for use in further model building.

A test of the full model with 5 predictors against a constant-only model was statistically significant, $\chi^{2}(5, N=11,412)=959.41, p<.001$, indicating that the predictors reliably distinguished between those respondents who intended to stay and those who intended to leave their department for other internal opportunities. Nagelkerke's $\mathrm{R}^{2}$ was moderate (Nagelkerke's $R^{2}=.17$ ) indicating that there was a substantial amount of variance unaccounted for in the model. Four of the five variables 
significantly contributed to the model. Table 3 shows regression coefficients, Wald statistics, odds ratios, and $95 \%$ confidence intervals for the odds ratios for each of the 5 predictors. The Wald statistics obtained for person-job fit (Wald $\chi^{2}=33.41, p<.001$ ), job satisfaction (Wald $\chi^{2}=197.38, p<.001$ ), stressful work environment (Wald $\chi^{2}=15.07, p$ $<.001$ ), and supervisor support (Wald $\chi^{2}=19.36, p<.001$ ) all showed to be significant predictors of intent to change departments. Teamwork was the only job-related predictor that was not statistically significant.

Table 3.

Direct Logistic Regression: Job-related Predictors and Intention to Change Departments

\begin{tabular}{lcccccc}
\hline & & & & & \multicolumn{2}{c}{$95 \%$ C.I. } \\
\cline { 4 - 7 } Variable & $\mathrm{B}$ & S.E. & Wald Test & Odds ratio & Lower & Upper \\
\hline Person-Job Fit & -.12 & .02 & $33.41^{* * *}$ & .89 & .86 & .93 \\
Job Satisfaction & -.19 & .01 & $197.38^{* * *}$ & .83 & .80 & .85 \\
Teamwork & .03 & .01 & 4.94 & 1.03 & 1.00 & 1.06 \\
Stressful Work Environment & .03 & .01 & $15.07^{* * *}$ & 1.03 & 1.01 & 1.04 \\
Supervisor Support & -.03 & .01 & $19.36^{* * *}$ & .98 & .97 & .99 \\
Constant & 1.17 & .26 & $20.13^{* * *}$ & 3.21 & & \\
\hline
\end{tabular}

$* * *=p<.001 * *=p<.01$

The odds ratios obtained for this model indicates that a one unit increase in person-job fit is associated with a $21 \%$ decrease in the likelihood of indicating intention to change departments, $O . R .=.89,95 \% C I[.86, .93])$. A one unit increase in job satisfaction is associated with a $27 \%$ decrease in the likelihood of indicating intention to change departments, $O . R .=.83,95 \% C I[.80, .85]$, whereas a one unit increase in 
supervisor support is only associated with a $2 \%$ decrease in the likelihood of intending to change departments, $O . R .=.98,95 \% C I[.97, .99]$. Moreover, the odds ratio for stressful work environment indicated that a one unit increase in stressful work environment is associated with a $3 \%$ increase in the likelihood of indicating intention to change departments, $O . R .=1.03,95 \% C I[1.01,1.04]$. Therefore the variables of person-job fit, job satisfaction, stressful work environment, and supervisor support distinguish between those who wish to stay in their current department and those who intend on leaving their department to pursue a job in another department. Thus, the stated hypotheses for personjob fit, job satisfaction and stressful work environment were supported, and the relationship between supervisory support and intention to change departments contradicted the expected relationship. The hypothesis regarding teamwork was not supported based on the criterion of meaningfulness needing to find significance at the $p=$ .01 level. As hypothesized, among the job-related predictors, lower job satisfaction seems to display the strongest association with intention to change departments (shown in the odds ratio for job satisfaction displayed in Table 3).

A second logistic regression analysis was conducted to explore the relationship of the job-related predictors with one's intention to change departments, when the demographic variables of age bands and education were accounted for. For that purpose, the demographic variables were entered into step 1 of the logistic regression model and the job-related predictors were added at step 2 of the model. As teamwork was not a significant predictor of intent to change departments in the previous analysis, it was not included in further tests. The second logistic regression model was built with input from the results of the first logistic model involving the job-related predictors. The second 
model aimed at examining whether the job-related predictors still contributed unique variance to the model over and above the influence of the demographic characteristics of age bands and education.

A test of the full model with 4 job-related predictors, and 2 demographic predictors (each dummy coded into 2 grouping variables and assessed in relation to a reference group) against a model with only the demographic predictors was statistically significant, $\chi^{2}(8, N=11,412)=1136.85, p<.001$, indicating that the job-related predictors significantly distinguished between those respondents who intended to stay and those who intended to leave their department above and beyond the demographic influences. Nagelkerke's $\mathrm{R}^{2}$ improved from the first model that had only the demographic variables of age bands and education as predictors (Nagelkerke's $R^{2}=.03$ ) to the full model with the job-related predictors added (Nagelkerke's $R^{2}=.20$ ), thus showing that job-related predictors of person-job fit, job satisfaction, stressful work environment, and supervisor support explain unique variance in respondents' intention to change departments, even in the presence of demographic variables. 
Table 4.

Sequential Logistic Regression: Demographic and Job-Related Factors, and Intention to Change Departments

\begin{tabular}{|c|c|c|c|c|c|c|}
\hline \multirow[b]{2}{*}{ Variable } & \multirow[b]{2}{*}{ B } & \multirow[b]{2}{*}{ S.E. } & \multirow[b]{2}{*}{ Wald Test } & \multirow{2}{*}{$\begin{array}{l}\text { Odds } \\
\text { ratio }\end{array}$} & \multicolumn{2}{|c|}{ 95\% C.I. } \\
\hline & & & & & Lower & Upper \\
\hline \multicolumn{7}{|l|}{ Block 1 (Demographics) } \\
\hline Age Bands & & & $143.76^{* * *}$ & & & \\
\hline AgeBand $_{1}($ Older vs. Youngest $)$ & 1.14 & .10 & $143.71 * * *$ & 3.12 & 2.59 & 3.76 \\
\hline AgeBand $_{2}$ (Older vs. Middle) & .77 & .10 & $62.65^{* * *}$ & 2.15 & 1.78 & 2.60 \\
\hline Education & & & $23.12 * * *$ & & & \\
\hline \multicolumn{7}{|l|}{ Education $_{1}$ (High School vs. } \\
\hline College/University training) & .01 & .09 & .01 & 1.01 & .85 & 1.20 \\
\hline \multicolumn{7}{|l|}{ Education $_{2}$ (High School vs. } \\
\hline Bachelor's+) & .34 & .08 & $16.99 * * *$ & 1.41 & 1.20 & 1.66 \\
\hline \multicolumn{7}{|l|}{ Block 2 (Job Factors) } \\
\hline Person-Job Fit & -.10 & .02 & $24.91 * * *$ & .90 & .87 & .94 \\
\hline Job Satisfaction & -.19 & .01 & $197.20^{* * *}$ & .83 & .81 & .85 \\
\hline Stressful Work Environment & .04 & .01 & $28.90^{* * *}$ & 1.04 & 1.03 & 1.06 \\
\hline Supervisory Support & -.02 & .01 & $17.16^{* * *}$ & .98 & .97 & .99 \\
\hline Constant & .27 & .26 & 1.09 & 1.31 & & \\
\hline
\end{tabular}

Organizational-level predictors of intention to change departments. A direct logistic regression analysis was performed on the organizational-level predictors using 
the ENTER method. The logistic regression was performed on intention to change departments as the outcome variable and with organizational commitment and career development and opportunities as the continuous predictor variables. Intention to change departments was coded as $0=$ stayers and $1=$ leavers. In the absence of previous research, the results of this analysis would be used to establish the significant organizational-level predictors for use in further model building.

A test of the full model with 2 predictors against a constant only model was statistically significant, $\chi^{2}(2, N=11,412)=1621.26, p<.001$, indicating that the organizational-level predictors reliably distinguished between those respondents who intended to stay and those who intended to leave their department for another department. Nagelkerke's $\mathrm{R}^{2}$ was .28 indicating the amount of variance accounted for by the organizational-level predictors, both of which significantly contributed to the model. Table 5 shows regression coefficients, Wald statistics, odds ratios, and $95 \%$ confidence intervals for the odds ratios for each of the predictors. The Wald statistics obtained for organizational commitment (Wald $\left.\chi^{2}=1057.30, p<.001\right)$ and career development opportunities (Wald $\chi^{2}=29.20, p<.001$ ) showed that these variables were significant predictors of intention to change departments (see Table 5). 
Table 5.

Direct Logistic Regression of Organizational-level Predictors and Intention to Change Departments

\begin{tabular}{lllllll}
\hline & & & & \multicolumn{2}{c}{$95 \%$ C.I. } \\
\cline { 5 - 7 } Variable & B & S.E. & Wald Test & Odds ratio & Lower & Upper \\
\hline $\begin{array}{l}\text { Organizational } \\
\quad \text { Commitment }\end{array}$ & -.44 & .01 & $1057.30^{* * *}$ & .65 & .71 & .74 \\
$\begin{array}{l}\text { Career Development } \& \\
\quad \text { Opportunities }\end{array}$ & .05 & .01 & $29.20^{* * *}$ & 1.06 & 1.04 & 1.08 \\
Constant & 1.27 & .12 & 122.03 & 3.57 & & \\
\hline$* * *=p<.001, * *=p<.01$ & & & & & &
\end{tabular}

The odds ratios obtained for this model indicate that a one unit increase in organizational commitment $(O . R .=.65,95 \% C I[.71, .74])$ was associated with a $35 \%$ decrease in the likelihood of reporting an intention to change departments, thus supporting the directional hypothesis for organizational commitment. The odds ratio for organizational commitment also supports the hypothesis that organizational commitment would be the most salient organizational-level predictor of intention to change departments. The odds ratios obtained for this model indicate that a one unit increase in career development and opportunities $(O . R .=1.06,95 \% C I[1.04,1.08])$ was associated with a $6 \%$ increase in the likelihood of reporting an intention to leave one's department. This finding contradicts the stated hypothesis for career development and opportunities that predicted the opposite relationship. 
A subsequent logistic regression was conducted to examine whether the organizational-level predictors would contribute unique variance to the model when the demographic characteristics associated with age bands and education were accounted for. Therefore, the demographic variables were entered into step 1 of the model and the organizational-level predictors were added to step 2 of the model. A test of the full model with 2 organizational-level predictors and 2 demographic predictors (each dummy coded into 2 grouping variables and assessed in relation to a reference group) against a model with only the demographic predictors was statistically significant, $\chi^{2}(6, N=11,412)$ $=1798.89, p<.001$, indicating that the organizational-level predictors reliably distinguished between those respondents who intended to stay and those who intended to leave their department for another department above and beyond the demographic influences. Nagelkerke's $\mathrm{R}^{2}$ improved from the first model with just the demographic predictors (Nagelkerke's $R^{2}=.03$ ) to the model that included the organizational-level predictors (Nagelkerke's $R^{2}=.31$ ). It is interesting to note that, in the presence of demographic factors, career development and opportunities became non-significant (Wald $\chi^{2}=4.93, p>.01, n s$ ). Table 6 below shows the sequential logistic regression analyses results. 
Table 6.

Sequential Logistic Regression with Organizational-level Predictors and Intention to Change Departments

$95 \%$ C.I.

Odds

Variable $\quad$ B S.E. Wald Test ratio Lower Upper

Block 1 (Demographics)

Age Bands

$147.11^{* * *}$

AgeBand $_{1}$ (Older vs. Youngest)

$1.21 \quad .10$

$147.05^{* * *} \quad 3.35$

$2.75 \quad 4.07$

AgeBand $_{2}$ (Older vs. Middle)

$.80 \quad .11$

$62.87^{* * *} \quad 2.22$

1.82

2.70

Education

$19.92^{* * *}$

Education $_{1}$ (High School vs.

College/University training)

$\begin{array}{lll}-.05 & .09 & .25\end{array}$

.96

.80

1.14

Education $_{2}$ (High School vs.

Bachelor's + )

$\begin{array}{llllll}-.31 & .09 & 12.21^{* * *} & 1.36 & 1.14 & 1.61\end{array}$

Block 2 (Organizational Factors)

Organizational Commitment

$\begin{array}{llll}-.43 & .01 & 986.38^{* * *} & .65\end{array}$

.63

.67

Career Development

Opportunities

$\begin{array}{lll}.02 & .01 & 4.93\end{array}$

1.02

1.00

1.04

Constant

$\begin{array}{llll}.74 & .14 & 28.16^{* * *} \quad 2.09\end{array}$

$* * *=p<.001,{ }^{* *}=p<.01$

A further logistic regression analysis was performed to explore whether the jobrelated and organizational-level predictors would work in an additive fashion contributing unique variance to the final model, beyond the variance explained by the demographic predictors of age bands and education. The groups of variables were added in steps, 
starting with the demographics, entering the job-related predictors at step 2 , and entering the organizational-level predictors at step 3. In this analysis, teamwork was not included as a job-related predictor and career development and opportunities was not included as an organizational-level predictor based on the non-significant findings associated with each of these two predictors in the previous analyses.

A test of the full model with the 2 categorical demographic predictors (dummy coded), the 4 job-related predictors, and the organizational-level predictor of organizational commitment against a model with the demographic predictors and the jobrelated predictors was statistically significant, $\chi^{2}(9, n=11,412)=1810.66, p<.001$, indicating that organizational commitment reliably distinguished between those respondents who intended to stay and those who intended to leave their department for another department above and beyond the demographic and job-related influences. Nagelkerke's $R^{2}$ improved from the model with the demographic and job predictors (Nagelkerke's $R^{2}=.20$ ) to the model that included organizational commitment (Nagelkerke's $R^{2}=.31$ ). The final model, which included demographic, job-related, and organizational-level predictors accounted for the most variance among the models. Job satisfaction, stressful work environment, and supervisor support were non-significant in this model indicating that person-job fit and organizational commitment reliably distinguished between those respondents who intended on staying and those who intended on changing departments above and beyond the demographic factors. Table 7 shows the sequential logistic regression analyses results. 
Table 7.

Sequential Logistic Regression with Demographic, Job-related, and Organizational-level Predictors and Intention to Change Department

\begin{tabular}{|c|c|c|c|c|c|}
\hline & & & & & 95\% C.I. \\
\hline Variable & B & S.E. & Wald Test & ratio & Lower \\
\hline
\end{tabular}

Block 1 (Demographics)

Age Bands

$154.27 * * *$

$\begin{array}{lcccccc}\text { AgeBand }_{1} \text { (Older vs. Youngest) } & 1.24 & .10 & 154.22 * * * & 3.44 & 2.83 & 4.19 \\ & & & & & & \\ \text { AgeBand }_{2} \text { (Older vs. Middle) } & .82 & .10 & 65.63 * * * & 2.26 & 1.86 & 2.76\end{array}$

Education

$20.78 * * *$

Education $_{1}$ (High School vs.

$\begin{array}{llllllll}\text { College/University training) } & -.2 & .09 & .06 & & .98 & .82 & 1.17\end{array}$

Educaiton $_{2}$ (High School vs.
Bachelor's + )
$.33 \quad .09$
$13.82 * * * \quad 1.39$
$1.17 \quad 1.65$

Block 2 (Job-related Predictors)

$\begin{array}{lllllll}\text { Person-Job Fit } & -.11 & .02 & 24.92 * * * & .90 & .86 & .94 \\ \text { Stressful Work Environment } & .02 & .01 & 5.37 & 1.02 & 1.00 & 1.03 \\ \text { Supervisory Support } & .01 & .01 & 6.61 & 1.02 & 1.00 & 1.03 \\ \text { Job Satisfaction } & .03 & .02 & 3.0 & 1.03 & 1.00 & 1.06\end{array}$

Block 3 (Organizational-level

Predictors)

Organizational Commitment

$\begin{array}{llllll}-.42 & .02 & 599.48 * * * & .66 & .64 & .68\end{array}$

Constant

$\begin{array}{llll}.57 & .27 & 4.47 & 1.77\end{array}$

$* * *=p<.001, * *=p<.01$ 


\section{Person -job fit as a moderator between stressful work environment and} intention to change departments. To test the interaction effect between stressful work environment and person-job fit, new variables were created by centering the person-job fit and the stressful work environment variables. Using logistic regression, stressful work environment (centered) and person-job fit (centered) were entered into block 1 of a logistic regression model using the ENTER method. In block 2 the interaction between person-job fit (centered) and stressful work environment (centered) was entered into the model using the ENTER method as well. The results suggested that the model with the interaction was significantly better than a constant only model; however, the individual contribution of the interaction failed to reach significance according to the criterion of meaningfulness specified for this study, since it contributed less than $2 \%$ variance to the model. Nagelkerke $R^{2}$ increased by $.4 \%$, which, although statistically significant, is not considered meaningful. Therefore, person-job fit did not moderate the relationship between stressful work environment and one's intention to change departments.

Organizational commitment as a mediator. Baron and Kenny (1986) proposed a four-tier process for discovering and evaluating whether mediation (full or partial) exists. The independent variable must be related to the dependent variable, the mediator must be related to the dependent variable and the independent variable, and that there is either no effect, regression coefficient is zero (full mediation), or that the strength of the relationship between the independent and dependent variable has decreased (partial mediation; Fraizer, Tix \& Baron, 2004). The results of the tested mediating hypothesis in this study are depicted in Figure 3 below. 
Figure 3: Mediation Model for Organizational Commitment with Paths and Regression Coefficients

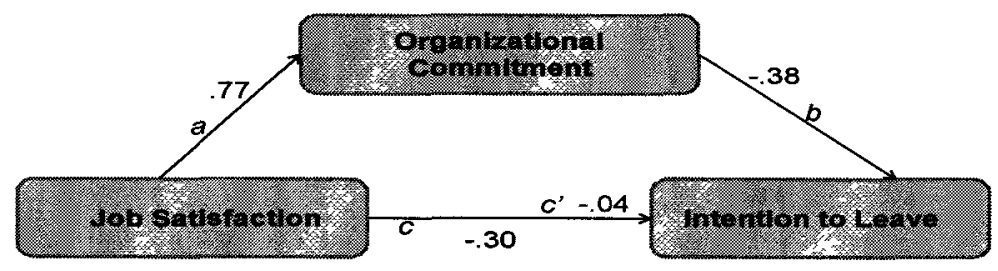

Step 1. The relationship between job satisfaction and intention to change departments was explored by regressing intention to change departments onto job satisfaction. A significant negative relationship was found, $B=-.30, z=-26.75, p<.001$. When the regression coefficient (log odds) was converted to the odds ratio, a one unit increase in job satisfaction was associated with a $25 \%$ decrease in employees indicating intention to leave their department for another department. This suggests that the first step which assesses path $c$ was met.

Step 2. The relationship between organizational commitment and job satisfaction was tested by regressing organizational commitment on job satisfaction. Step two, which evaluates path $a$, was satisfied as a significant positive relationship was found, $B=.77, t$ $=84.62, p<.001$ between organizational commitment and job satisfaction. This relationship indicates that the more satisfied employees are with their job, the more organizational commitment they experience. 
Step 3. The mediator (organizational commitment) was examined for its relation with intention to change departments (path b) and the regression coefficient was significant, $B=-.38, z=-28.08, p<.001$. When the $\log$ odds $(B)$ were converted to an odds ratio ( $O R=.69$ ), the results suggests that for every one unit increase in organizational commitment the likelihood of indicating intention to change departments decreases by $31 \%$. This finding indicates that the step 3 condition is met whereby path $b$ was significant. Path c', which examines the relationship between job satisfaction and intention to change departments when controlling for organizational commitment, was observed and was smaller than path c, $B=-.04, z=-2.49, p=.01$, indicating that there was a partial mediation effect (Fraizer et al., 2004). The odds ratio obtained for this association $(\mathrm{OR}=.97)$ indicates that when controlling for organizational commitment, a one unit increase in job satisfaction is associated with a $3 \%$ decrease in the likelihood of indicating intention to change departments.

Testing the mediated effect using bootstrapping. STATA was used to conduct the bootstrapping significance test of the mediation effect. The Baron and Kenny method indicates that organizational commitment partially mediates the relationship between job satisfaction and intention to change departments; however, it does not indicate whether it is a significant indirect effect. Bootstrapping ${ }^{10}$ was used whereby 500 samples were drawn from the data, regression weights were generated, and the mean of the generated samples was presented. The 500 replications yielded an estimated mediation effect of -.33 with a standard error of .01 . The confidence interval around the mediated effect produced

\footnotetext{
${ }^{10}$ Bootstrapping is a statistical technique that uses regression weights created from large amounts of replications, generated from random samples with replacements of the data to avoid overfitting (Tabachnick \& Fidell, 2007).
} 
by STATA was $95 \% \mathrm{CI}[-.36,-.31]$, which does not include zero further supporting that there is in fact a significant mediation effect.

\section{Discussion}

The overall purpose of the present study was to examine the association of demographic, job-related, and organizational-level factors with Canadian federal public servants' intention to change jobs within the public service. As expected, employees in younger age bands and with higher levels of education were most likely to indicate a desire to take on a new position in a different department/agency. The job-related predictors including person-job fit, job satisfaction, stressful work environment, and supervisor support also demonstrated significant association with employees' intention to leave their department for an opportunity in another department/agency. Finally, the organizational-level predictors of organizational commitment and career development and opportunities were also significantly associated with employees' intention to change departments.

\section{Demographic Predictors}

Past research has suggested that it is the younger and more educated employees who move from job to job seeking better opportunities and working conditions (De Vos et al., 2008; Ito, 2003; Otto et al., 2010; Tanova \& Holtom, 2008). This study complimented past research by demonstrating that within the federal Public Service of Canada, the employees who are most likely to indicate an intention to leave their department for opportunities in other departments/agencies are those with higher educational attainment (Bachelor's degree and above) and those who are younger than 
the Older generation (Youngest, Middle). Interestingly, these two demographic characteristics accounted for only a small proportion of the reason why employees intend to leave their departments, thus showing the need to also consider factors from employees' work environment.

\section{Job-related Factors}

The results from this study suggest that when the job-related factors are examined alone, that person-job fit, job satisfaction, and supervisory support have a positive influence on employees' intention to stay with their current department. Moreover, the less stressful employees' work environment was perceived to be, the more likely they were to stay in their current position, thus reducing the likelihood for intra-organizational mobility. When the demographic characteristics of age bands and education were accounted for, these job-related factors were still significant predictors of employees' intention to change departments. Therefore, in the absence of research examining employees' intention to leave their department for other internal opportunities, this study helps to fill the gap by noting that worse person-job fit, lower job satisfaction, less supervisor support and a stressful work environment all influence employees' intention to leave their department for a position in another department/agency.

These findings are aligned with previous research that suggests that low job satisfaction is associated with greater intention to change departments or to leave the organization (Jackofsky \& Peters, 1983; Liu, Liu, \& Hu, 2010; Tett \& Meyer, 1993). Therefore, it appears that by increasing job satisfaction the odds of employees intending to remain with their current department would increase, thus possibly reducing intraorganizational mobility within the Public Service. 
Liu, Liu and $\mathrm{Hu}(2010)$ found greater person-organization fit was associated with lower turnover intentions among Chinese public servants; this finding is aligned with the current study's finding that person-job fit was negatively associated with intention to leave the department among Canadian public servants. This is an interesting finding because the relationship between person-job fit and intention to leave the department for internal opportunities has not been previously explored in a public service context. Moreover, person-job fit was one of the main predictors of intention to change departments, thus highlighting the importance of this construct and leaving room for future research to examine it further in its relation to intra-organizational mobility

Ramlall (2003) showed that leadership and performance feedback influenced employees' decision to leave the organization. The supervisor support variable, in the current study, reflected a supportive manager-employee relationship that included the manager providing the employee with feedback on their work. The results of the present study suggest that the more supervisor support employees had, the less likely they were to have intentions to leave their department therefore highlighting the point that employees like to remain with good supervisors. However, these results contradicted the stated hypothesis for this relationship, which was based on Cho, Johanson, and Guchait's (2009) study and on the expectation of a positive association as employees in the federal Public Service of Canada generally need to move in order to advance their careers. It was speculated that supervisors may realize that in order for their employees to grow and develop as professionals, they would need to seek opportunities in other departments. To gain further understanding of this relationship, future research may wish to address the interaction of supervisor support and career development. 
The association of supervisor support with intention to leave the department was not particularly strong in this study, thus making it difficult to have conclusive statements about this relationship. Moreover, supervisor support, which is a positive outlook on supervision, is different from toxic supervision, which is more readily studied in relation to turnover intention and turnover (Ferris, 1985; Tepper, 2000). It would be expected that toxic supervision would show a stronger positive association with one's intention to change departments. Further research exploring the relationship between supervisor support, toxic supervision and one's intention to change departments would be warranted. Although Curry (2009) and Ramlall (2003) showed that teamwork had a negative association with an employee's decision to leave their organization, their finding was not supported by the present study as teamwork did not influence employees' intention to leave the department for other internal opportunities. It might be speculated that teamwork is usually valued, but might not necessarily be a push factor that would mobilize employees to seek other opportunities. It could be further speculated that teamwork would contribute to one's job satisfaction. Therefore, future research may wish to examine a mediated relationship between teamwork, job satisfaction, and intention to leave the department.

The Government of Canada could be a highly stressful work environment for some, with changing priorities, high mobility, many approval stages, demanding deadlines, and depleting resources. It is therefore of no surprise that a stressful work environment influenced employees' intention to leave their department. Whereas Ito (2003) examined "promotion stress" which appears to be related to experiencing stress in relation to a lack of career progression opportunities, this study examined a more holistic 
view of a stressful work environment. As there is no study that we are aware of, to date, that examines the specific stressful environment experienced by public servants and its relationship to intention to leave, the present study contributes to understanding the role that a stressful work environment could play on intra-organizational mobility.

Nevertheless, when the demographic characteristics and the job-related factors were accounted for, they contributed to explaining $20 \%$ of the variance in employees' intention to change departments, suggesting that there might still be other reasons for employees' intention to leave their department to pursue jobs in other departments.

\section{Organizational Predictors}

To further explore what influences employees' intention to leave the department for opportunities in other departments, the organizational-level predictors of organizational commitment and career development and opportunities were examined. Whereas Curry's (2009) research suggested that career development was an important factor for employees in the Australian Public Service, it did not show the same importance in Canada as it failed to show significance above and beyond the presence of demographic factors. Moreover, although a significant relationship was found for career development opportunities, when only examining the organizational factors, interpreting the results as meaningful should be cautioned as the assumption of linearity in the logit was not met for this variable and the direction of the relationship changed from the bivariate correlations to the logistic regression.

The finding that organizational commitment is negatively related to intention to leave the department is aligned with past research in the private sector (Kondratuk et al., 2004; Tett \& Meyer, 1993) and in the public service (Ito, 2003; Ito \& Brotheridge, 2005). 
Organizational commitment showed to be the most predominant factor even in the presence of job-related and demographic factors. Therefore, this study highlighted that when employees are highly committed to their department, they will report intentions to remain in their current position, therefore increasing retention to the department and reducing intra-organizational mobility. To further understand in more depth the nature of organizational commitment in the federal Public Service of Canada and the direction of this commitment, i.e., whether towards one's department or the Public Service, it would be worth to empirically examine the different kinds of commitment and its association with one's department and the Public Service in general.

When the three groups of variables (demographic, job-related and organizationallevel) were examined together in a single model, only person-job fit and organizational commitment were influential factors, above the demographic factors, thus bringing attention to these two variables as important determinants of employees' intention to change departments. In the current study, when organizational commitment and job satisfaction were added to the same model, job satisfaction no longer showed a significant relationship to intention to leave the department indicating that there is quite a bit of shared variance among job satisfaction and organizational commitment. Interestingly, Tett and Meyer (1993) showed that job satisfaction and organizational commitment are unique predictors of intention to leave, but this finding was not replicated in the current study. Moreover, Tett and Meyer (1993) noted that there was a stronger association between job satisfaction and intention to leave than between organizational commitment and intention to leave. The present study found that the 
strength of the bivariate associations were fairly similar with organizational commitment having a stronger influence on intention to change departments.

A significant partial mediation effect was found in this study for organizational commitment, indicating that job satisfaction is associated with intention to change departments through organizational commitment. Therefore as job satisfaction decreases, so does organizational commitment, which in turn is associated with a greater likelihood of reporting an intention to change departments. This mediated relationship is worth noting as it contributes to the understanding of the relationship between job satisfaction, organizational commitment and intention to leave in a public service context.

\section{Theoretical Contributions}

In view of the limited research on intra-organizational mobility, this study contributes not only to the understanding of the factors associated with employees' intention to change departments within the federal Public Service of Canada, but also to the understanding of intra-organizational mobility in general. The present study showed that employees do not intend to change departments solely because of the age band they belong to or the educational attainment they have. While these factors are important, they only influenced the intention to leave the departments to a small extent. The study examined different job-related and organizational-level predictors that could help explain the desirability associated with leaving the department in pursuit of opportunities in other departments. Interestingly, the most important factors associated with employees intending to remain in or leave their department were person-job fit and organizational commitment. 
The integration of Becker's (1960) side-bet theory and March and Simon's (1958) ease and desirability theory provide a context for understanding the findings of this study. Through the saliency of the person-job fit and the organizational commitment factors in their association with employees' intentions to change departments, this research in a way relates to both the Becker's theory of commitment and the March and Simon's ease and desirability theory. Uncovering that organizational commitment was the strongest predictor of employees' intent to stay with their department could be interpreted within Becker's theory of commitment that when it is perceives as too costly to leave, employees remain in their organization. However, in line with March and Simon's ease and desirability theory, public servants can change their work conditions while keeping their side-bets to the organization, by moving internally to different positions. As noted earlier, it is relatively easy and at low cost to the employees to move to a new department or agency. Moreover, the employees who were more educated were more likely to report an intention of changing departments, which could support the idea that some employees are more able to move than others based on their personal circumstances including their acquired skills and experience.

Based on this study's findings, coupled with the mobility statistics for the federal Public Service of Canada that show a high number of people applying to various federal jobs, a very low number of people leaving the federal Public Service for other than retirement reasons, and a high number of people moving internally, it might be speculated that federal Public Service is a desirable employer and employees may be keeping side-bets that retain them in the public service once they are in, while addressing a perceived lack of person-job fit through internal mobility. Exploring further this study 
sample's intention to change departments by geographic location, the highest intent to change departments was reported in the National Capital Region (12.3\%), where also more internal employment opportunities exist due to the higher concentration of federal departments and agencies' headquarters and offices. This finding again aligns with March and Simon's ease and desirability theory propositions.

The finding that increasing organizational commitment would help keep employees from intending to leave the department is aligned with past research and is important. However, the contribution that person-job fit made is of more interest. There are over a million applications submitted each year for jobs in the public service, with the same applicants applying to multiple positions. It may be speculated that applicants would take any job to be a public servant. Therefore, it may not be that surprising then that the main job-related factor that influenced employees' intention to leave their department was person-job fit. Moreover, it appears as if it is the younger and more educated employees who are seeking these better fitting jobs.

\section{Methodological Contributions}

The Public Service Employee Survey 2008 is a survey that was developed for a specific population. The current study developed measures of recognized organizational constructs using the Public Service Employee Survey (2008) items and examined their psychometric properties, thus demonstrating the reliability of these specific measures tailored to the organizational context of the federal Public Service of Canada. The mediated relationship explored in this study was tested through logistic regression analysis, which is not a common practice and is worth noting from a methodological point of view. 
The sample of the survey is also worth noting as it included federal public servants of various demographics from all across Canada and thus allowed to examine intra-organizational mobility, along with demographic, job-related, and organizationallevel predictors associated with intentions to change departments in a widely distributed sample representing one of the largest employers in Canada. With the scarcity of research conducted in a public service context in this domain, this research contributes to knowledge and sets the stage for future research to build on.

\section{Practical Contributions}

In general, the findings of the job-related and organizational-level predictors in their relationship to employees' intention to change departments in the present study validate findings from previous research in the context of the federal Public Service of Canada but also bring potential for strategic human resources planning initiatives. Given the higher mobility rate in the federal Public Service of Canada when compared to other public services such as the American, the Australian and the British ones, these findings could be used to help understand the reasons behind voluntary intra-organizational mobility and therefore aid in strategic human resources planning.

In an era of depleting resources and downsizing within the federal Public Service knowing the reasons why an employee intends to change departments can help from a strategic perspective by targeting the most salient predictors as keys to developing initiatives. Whereas movement within the federal Public Service of Canada is relatively easy and employees move for various reasons, above and beyond demographic factors, those push factors would still remain even if the ease of movement becomes more limited. 
Initiatives to improve the high mobility rate would be worth pursuing even on the dawn of potential downsizing. When times are tough, organizations would need to put resources into ensuring their employees are content. Such initiatives would not only address retention but also individual and organizational well-being. Based on the findings of this study, the federal Public Service should target person-job fit and organizational commitment in strategic personnel initiatives in the domain of intra-organizational mobility. While some mobility is essential in organizations, when needing to deal with increased mobility, it would be important to ensure that employees have strong personjob fit. This would help keep them in their positions longer, therefore reducing the time and cost burden associated with hiring and training that occurs with every position that needs to be filled.

\section{Limitations}

There were many limitations with regard to this study, mostly stemming from the fact that it was an archival study that used pre-existing measures designed for a specific population. As the outcome measure was dichotomous, there were limitations with regard to the type of analyses that could be performed. Logistic regression was the only viable multivariate analysis that was suitable for use. As well, the categorical nature of the age variable made it difficult to precisely describe the age distribution of respondents and develop age categories for the present study. Therefore, grouping in age bands was used instead to explore in this study what was found in previous research, i.e., that younger employees are more mobile than older ones.

The present study was cross-sectional in nature and therefore inferences about causality could not be made. The violation of the linearity in the logit assumption limits 
the results to the specific sample and therefore generalizing the results of the current study with respect to the career development and opportunities variable, to the entire Canadian public service should be cautioned.

Finally, a limitation of this study was that the measures were developed for the public service thus making it difficult to compare in detail findings with those from studies that use recognized measures of organizational constructs such as job satisfaction, person-job fit, and organizational commitment. For example, whereas the results in this study suggest that organizational commitment is a key predictor of intention to change departments, the current measure makes no distinction between the types of commitment.

\section{Future Research and Conclusions}

The present study contributes to the understanding of intra-organizational mobility and the factors that are associated with employees' intentions to leave their departments for opportunities in other departments. Although this study was informative from both knowledge and practice point of view, there was still considerable variance unaccounted for in the model, thus highlighting the importance of studying other predictors. Recent newspaper reports have been released indicating that public servants are struggling with respect to health outcomes (Butler, 2011). Given the importance of health outcomes for both individual and organizational well-being, it would be worthwhile to consider expanding the Public Service Employee Survey to explore health related outcomes. Future research could examine dimensions of well-being, coping, work-life balance, or life satisfaction and thus enable a more holistic view of the Canadian federal public servants and perhaps elucidate what other factors could be associated with one's intention to leave or stay with their current department. 
An interesting expansion of this study could address public servants' type of organizational commitment by examining the well-recognized in the literature normative, continuance and affective commitment (Allen \& Meyer, 1996). This would allow to empirically explore Becker's side-bet theory as to understand the nature of employees association with their employer. It would also be worthwhile to further examine on one side the employees' relationship to their department and on the other side their relationship to the Canadian Public Service in order to further understand their organizational commitment.

In conclusion, in view of the limited available research, this study contributed to the understanding of voluntary intra-organizational mobility, the job-related and organizational-level predictors associated with it, and particularly in the context of the federal Public Service of Canada. The findings showed that the reasons employees intend to change departments are aligned with the reasons employees intend to change organizations. In addition to the contribution to knowledge, methodological and practical contributions were identified, along with the study's limitations. Suggestions for future research were made building upon the current findings to allow for developing a more indepth understanding of intra-organizational mobility and for building a more holistic understanding of the federal Public Service of Canada. 


\section{References}

A Dictionary of Business and Management. (2006). Person-job fit. Retrieved from: http://www.encyclopedia.com/doc/1018-personjobfit.html

APS. (2011). Branching out. 1-1. Retrieved from http://www.apsjobs.gov.au/ApsRegisterHomePage.aspx?mn=BranchingOut

APS. (nd). State of the Service 2008-2009, 1-256. Retrieved from http://www.apsc.gov.au.

APSC. (2003). Public service leadership; emerging issues. National Institute for Governance, 1-44.

Allen, N. J., \& Meyer, J. P. (1996). Affective, continuance, and normative commitment to the organization: An examination of construct validity. Journal of Vocational Behavior, 49 , 252-276. DOI: 0001-8791/96

Allison, P. D. (2000). Multiple imputation for missing data: A cautionary tale. Sociological Methods and Research, 28, 301-309.

Armstrong-Stassen, M. (2003). Job transfers during organizational downsizing: a comparison of promotion and lateral transfers. Group \& Organizational Management, 28, 392-414. DOI: 10.1177/1059601102250824.

Arthur, M.B., (1994). The boundaryless career: A new perspective for organizational inquiry. Journal of Organizational Behaviour, 15, 295-306.

Arthur, M.B., Khapova, S.N., \& Wilderom, C.P.M. (2005). Career success in a boundaryless career world. Journal of Organizational Behavior, 26, 177-202. DOI:10.1002/job.290 
Arthur, M.B., \& Rousseau, D.M. (1996). The boundaryless career: A new employment principle for a new organizational era. New York: Oxford University Press.

Baron, R. M., \& Kenny, D. A. (1986). The moderator-mediator. Journal of Personality and Social Psychology, 51, 1173-1182.

Becker, H. S. (1960). Notes on the concept of commitment. American Journal of Sociology. 66, 32-42.

Beeher, T.A., \& Taber, T.D. (1993). Perceived intra-organizational mobility: reliable versus exceptional performance as means to getting ahead. Journal of Organizational Behavior, 14, 549-594. 0894-3796/93/060579-16

Belcourt, M., Bohlander, G., \& Snell, S. (2008). Managing Human Resources, Toronto: Nelson.

Blanchard, A. L., Welbourne, J., Gilmore, D., \& Bullock, A. (2009). Followership styles and employee attachment to the organization. Psychologist-Manager Journal, 12, $111-131$.

Butler, D. (2011, June 28). PS disability claims soaring: Mental health issues account for 47.3\% of claims in 2010. Ottawa Citzen. Retrieved from http://www.infomedia.gc.ca

Cho, S., Johanson, M. M., \& Guchait, P. (2009). Employees intent to leave: A comparison of determinants of intent to leave versus intent to stay. International Journal of Hospitality Management, 28, 374-381.

Cohen, J., Cohen, P., West, S.G., \& Aiken, L.S. (2003). Applied multiple regression/correlation ( $3^{\text {rd }}$ ed.). Mahwah, NJ: Lawrence Erlbaum Associates.

Curry, K. (2009). Does support for VET reduce employee churn? A case study in local government. National Centre for Vocational Educational Research, 1-31. 
De Cuyper, N., \& De Witte, H., (2007). Job insecurities in temporary versus permanent workers: Associations with attitudes, well being, and behaviour. Work and Stress, 21, 65-84. DOI: $10.1080 / 02678370701229050$

De Lange, A.H., De White, H., \& Notelaers, G. (2008). Should I stay or should I go? Examining longitudinal relations among job resources and work engagement for stayers versus movers. Work \& Stress, 22, 201-223.

De Vos, A., Dewettinck, K., \& Buyens, D. (2008). To move or not to move? The relationship between career management and preferred career moves. Employee Relations, 30, 156-175. DOI: 10.1108/01425450810843348.

Dobreva-Martinova, T., Villeneuve, M., Strickland, L., \& Matheson, K. (2002). Occupational role stress in the Canadian forces: Its association with individual and organizational well-being, Canadian Journal of Behavioural Science, 34, 111-121.

Donnelly, R. (2009). Career behaviour in the knowledge economy: experiences and perceptions of career mobility among management and IT consultants in the UK and the USA. Journal of Vocational Behaviour, 75, 319-328.

DOI:10.1016/j.jvb.2009.04.005.

Farber, H.S. (1998). Mobility \& stability: the dynamics of job change in labor markets. Working Paper No. 400, Industrial Relations Section, Princeton University. Farber, H.S. (1997a). Trends in long-term employment in the united states, 1979-96. Working Paper No. 384, Industrial Relations Section, Princeton University. In Farber, H.S. (1998). Mobility \& stability: the dynamics of job change in labor markets. Working Paper No. 400, Industrial Relations Section, Princeton University. 
Farber, H.S. (1997b). Job creation in the United States: good jobs or bad? Working Paper No. 385, Industrial Relations Section, Princeton University. In Farber, H.S. (1998) Mobility \& stability: the dynamics of job change in labor markets. Working Paper No. 400, Industrial Relations Section, Princeton University.

Ferris, G. R. (1985). Role of leadership in the employee withdrawal process: A constructive replication. Journal of Applied Psychology, 70, 777-781. doi:10.1037/0021-9010.70.4.777

Frazier, P.A., Tix, A.P., \& Barron, K.E. (2004). Testing moderator and mediator effects in counseling psychology research. Journal of Counseling Psychology, 51(1), 115134.

Garavan, T.N., \& Coolahan, M. (1996). Career mobility in organizations: implications for development - part 1. Journal of European Industrial Training, 20, 689-708.

Gregg, P., \& Wadsworth, J. (2002). Job tenure in Britain, 1975-98. Is a job for life or just for Christmas? Oxford Bulletin of Economics and Statistics, 64, 111-134.

DOI: $10.1111 / 1468-0084.00015$

Griffeth, R. W., Hom, P. W., \& Gaertner, S. (2000). A meta-analysis of antecedents and correlates of employee turnover: Update, moderator tests, and research implications for the next millennium. Journal of Management, 26, 463-488.

Hayes, A. F., \& Matthes, J. (2009). Computational procedures for probing interactions in OLS and logistic regression: SPSS and SAS implementations. Behavior Research Methods, 41, 924-936. 
Hayes, L. J., O'Brien-Pallas, L., Duffield, C., Shamian, J., Buchan, J., Hughes, F., et al. (2006). Nurse turnover: A literature review. International Journal of Nursing Studies, 43, 237-263.

Hausknecht, J.P., Hiller, N.J., \& Vance, R.J. (2008).Work-unit absenteeism: Effects of satisfaction, commitment, labor market conditions, and time. Academy of Management Journal, 51, 1223-1245

.Hsu, M.K., Jiang, J.J., Klein, G., \& Tang, Z. (2003). Perceived career incentives and intent to leave. Informational and management, 40, 361-369.

Ito, J. (2003). Career mobility and branding in the civil service: An empirical study. Public Personnel Management, 32, 1-21.

Ito, J. K., \& Brotheridge, C. M. (2003). Exploring the predictors and consequences of job insecurity's components. Journal of Managerial Psychology, 22, 40-64. DOI: $10.1108 / 02683940710721938$

Ituma, A., \& Simpson, R. (2009). The 'boundaryless' career and career boundaries: applying an institutionalist perspective to ICT workers in the context of Nigeria. Human Relations, 62, 727-761. DOI: 10.1177/0018726709103456

Jackofsky, E.F., \& Peters, L. H. (1983). Job turnover versus company turnover: reassessment of the march and simon participation hypothesis. Journal of Applied Psychology, 68, 490-495.

Kalleberg, A.L., \& Mastekaasa, A. (2001). Satisfied movers, committed stayers: the impact of job mobility on work attitudes in Norway. Work and Occupations, 28, $183-$ 209. 
Koch, J.L., \& Steers.R M. (1978). Job attachment, satisfaction and turnover among public sector employees. Journal of Vocational Behavior, 12, 119-128. 0001-8791/78/01210119.

Kondratuk, T.B., Hausdorf, P.A., Korabik, K., \& Rosin, H.M. (2004). Linking career mobility with corporate loyalty: how does job change relate to organizational commitment. Journal of Vocational Behaviour, 65, 332-349. DOI:

10.1016/j.jvb.2003.08.004

Lai, L., \& Kapstad, J.C. (2009). Perceived competence mobilization: an exploratory study of predictors and impact on turnover intentions. The International Journal of Human Resource Management, 20, 1985-1998. DOI: 10.1080/09585190903142423.

Liljegren, M., \& Ekberg, K. (2009). Job mobility as predictor of health and burnout. Journal of Occupational and Organizational Psychology, 82, 317-329. DOI: $10.1348 / 096317908 \times 332919$

Liu, B., Liu, J., \& Hu, J. (2010). Person-organizational fit, job satisfaction, and turnover intention: An empirical study in the Chinese public service. Social Behavior and Personality, 38, 615-626. DOI: 10.2224/sbp.2010.38.5.615.

Macdonald, D. (2011). The shadow public service: the swelling ranks of federal government outsourced workers. Canadian Center for Policy Alternatives. 1-28.

March, J.G., \& Simon, H.A. (1958). Organizations. New York: Wiley.

McDonald, P., Brown, K., \& Bradley, L. (2005). Have traditional career paths given way to protean ones? Evidence from senior managers in the Australian public service. Career Development International, 10, 109-129. Doi: 10.1108/13620430510588310 
MacKinnon, D. P., Lockwood, C. M., Hoffman, J. M., West, S. G., \& Sheets, V. (2002). A comparison of methods to test the significance of the mediated effect. Psychological Methods, 7, 83-104.

Meyer, J. P., \& Allen, N. J. (1984). Testing the "side-bet theory" of organizational commitment: Some methodological considerations. Journal of Applied Psychology, $69,372-378$.

Meyer, J. P., Stanley, D. J., Herscovitch, L., \& Topolnytsky, L. (2002). Affective, continuance, and normative commitment to the organization: A meta-analysis of antecedents, correlates and consequences. Journal of Vocational Behavior, 61, 2052.

Miller, L.E., Powell, G.N., \& Seitzer, J. (1990). Determinants of turnover among volunteers. Human Relations, 43, 901-917. doi: 0018-7267/90/0900-0901

Maimon, Z., \& Ronen, S. (1978). Measures of job facets satisfaction as predictors of the tendency to leave or the tendency to stay with an organization. Human Relations, 31, 1019-1030. doi:0018-7267/78/1200-1019

Mobley, W. H. (1977). Intermediate linkages in the relationship between job satisfaction and employee turnover. Journal of Applied Psychology, 237-240.

Mobley, W. H., Horner, S. O., \& Hollingsworth, A. T. (1978). An evaluation of precursors of hospital employee turnover. Journal of Applied Psychology, 63, 408414.

Murrel, A.J., Hanson Frieze, I., \& Olson, J.E. (1996). Mobility strategies and career outcomes: a longitudinal study of MBAs. Journal of Vocational Behavior, 49, 324335. 
Ng, T.W.H., Sorensen, K.L., Eby, L.T., \& Feldman, D.C. (2007). Determinants of job mobility: a theoretical integration and extension. Journal of Occupational and Organizational Psychology, 80, 363-386. doi: 10.1348/096317906X130582

Nunnally, J. C. (1978). Psychometric theory (2nd ed.). New York: McGraw-Hill. Office of National Statistics (ONS) (2010). Civil Service Statistics. Statistical Bulletin November, 1-24. Retrieved from http://www.statistics.gov.uk/pdfdir/cs1110.pdf Ostroff, C., \& Clark, M.A. (2001). Maintaining an internal market: antecedents of willingness to change jobs. Journal of Vocational Behaviour, 59, 425-453. doi: $10.1006 /$ jvbe. 2001.1801

Otto, K., Dette-Hagenmeyer, D.E., \& Dalbert, C. (2010). Occupational mobility in members of the labor force: explaining the willingness to change occupations. Journal of Career Development, 36, 262-288. doi: 10.1177/0894845309345842.

Porter, L.W., \& Steers, R.M. (1973). Organizational, work, and personal factors in employee turnover and absenteeism. Psychoiogicai Buuetin, 80, 156-176.

Porter, L.W., Steers, R.M., Mowday, R.T., \& Boulian, P.V. (1974). Organizational commitment, job satisfaction, and turnover among psychiatric technicians. Journal of Applied Psychology, 59, 603-609

Preacher, K. J., \& Hayes, A. F. (2004). SPSS and SAS procedures for estimating indirect effects in simple mediation models. Behavior Research Methods, Instruments, \& Computers, 36, 717-731.

Preacher, K. J., \& Hayes, A. F. (2008). Asymptotic and resampling strategies for assessing and comparing indirect effects in multiple mediator models. Behavior Research Methods, 40, 879-891. 
Public Service Commission of Canada (2008). Study on mobility of public servants. (ISBN: 978-1-100-10455-3) Retrieved from http://www.psc-cfp.gc.ca/adtvrf/rprt/2008/mob/hl-ps-eng.htm

Ramlall, S. (2003). Managing employee retention as a strategy for increasing organizational competitiveness. Applied H.R.M.Research, 8, 63-72.

Schafer, J. L. (1997). Analysis of incomplete multivariate data. London: Chapman \& Hall.

Schaufeli, W. B., Bakker, A. B., \& Van Rhenen, W. (2009). How changes in job demands and resources predict burnout, work engagement and sickness absenteeism. Journal of Organizational Behavior, 30, 893-917.

Schermarhom, J.R. (2009). Exploring Management, New Jersey: Wiley \& Sons.

Schwab, D.P. (1981). Contextual variables in employee performance-turnover relationships. Academy of Management Journal, 34, 966-975.

Sinnot, G.S., Madison, G.H., \& Pataki, G.E. (2002). Employee retention: Report of the employee retention workgroup. NYS Department of Civil Service, 1-62.

Smith, A. (2009). The roles and responsibilities of central agencies. Library of Parliament: International Affairs, Trade and Finance Division, 1-17.

Spell, C.S., \& Blum, T.C. (2000). Getting ahead: organizational practices that set boundaries around mobility patterns. Journal of Organizational Behavior, 21, 299314.

Swaen, G. M. H., Kant, I., Van Amelsvoort, L. G. P. M., \& Beurskens, A. J. H. M. (2002). Job mobility, its determinants, and its effects: Longitudinal data from the maastricht cohort study. Journal of Occupational Health Psychology, 7, 121-129. 
Tabachnick, B.G., \& Fidell, L.S. (2007). Using multivariate statistics (5th Ed). Boston: Pearson

Tanova, C., \& Holtom, B.C. (2008). Using job embeddedness factors to explain voluntary turnover in four European countires. The International Journal of Human Resource Management, 19, 1553-1568. doi: 10.1080/09585190802294820

TBS (2011). EC development program. TBS intranet.

Tepper, B. J. (2000). Consequences of abusive supervision. Academy of Management Journal, 43, 178-190. doi:10.2307/1556375

Tett, R.P., \& Meyer, J.P. (1993). Job satisfaction, organization commitment, turnover intention, and turnover: Path analyses based on meta-analytic findings. Personnel Psychology, 46, 259- 293.

Trendle, B., \& Tunny, G., (2003). Turnover of permanent staff in the Queensland public service. Labor Market Research; Department of Employment and Testing, 1-18.

USOPM (2010). A new day in the civil service. Report to Congress. United States Office of Personnel Management, 1-9.

Valcour, P.M., \& Tolbert, P.S. (2003). Gender, family and career in the era of boundarylessness: determinants and effects of intra and inter-organizational mobility. International Journal of Human Resource Management, 14, 768-787. doi:10.1080/0958519032000080794

Wallace, L., \& Trinka, J. (2009). Leadership and employee engagement. Public Management, 91, 10-13. 
Way, S.A., Lepack, D.P., Fay, C.H., \& Thacker,J.W. (2010).Contingent workers' impact on standard employee withdrawal behaviors: Does what you use them for matter? Human Resource Management, 19, 109-138. doi: 10.1002/hrm.20336.

Weller, P., Smart, A. \& Georges, A.M. (1980). Mobility in the Australian public service. Australian Journal of Public Administration, $X X X L X, 18-29$. 


\section{Appendices}

\section{Appendix A: Stratified Sample}

Table 1: The highlighted area represents the 9 strata used to stratify the sample.

\begin{tabular}{|c|c|c|c|c|}
\hline & High School & $\begin{array}{l}\text { College Diploma } \\
\text { /Below } \\
\text { Bachelor's } \\
\text { Degree }\end{array}$ & $\begin{array}{r}\text { Bachelor's } \\
\text { Degree and } \\
\text { above }\end{array}$ & Total \\
\hline $\begin{array}{r}\text { Youngest }(< \\
30)\end{array}$ & & & $x^{2}(2.50)$ & 4050 \\
\hline $\begin{array}{r}\text { Middle (30- } \\
44) \\
\end{array}$ & 01850 & 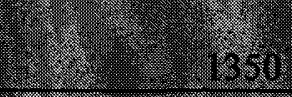 & 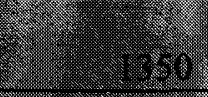 & 4050 \\
\hline $\begin{array}{r}\text { Older (45- } \\
59) \\
\end{array}$ & 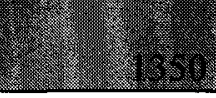 & & 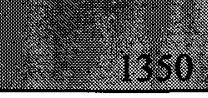 & 4050 \\
\hline Total & 4050 & 4050 & 4050 & 12150 \\
\hline
\end{tabular}




\section{Appendix B: Questions from the PSES 2008}

\section{Intention to Change Departments}

Q1: Do you intend to leave your department or agency in the next two years?

- 1: Yes

- 2: No (0)

- 3: Not Sure (0)

Q2: Please indicate your reason for leaving:

- 1: To retire

- 2: To pursue a job in another department or agency (1)

- 3: To pursue a job outside the federal Public Service

- 4: Other

\section{Age Groups}

Q1: What is your age group?

- Up to 24 years

- 25 to 29 years

- 30 to 34 years

- 35 to 39 years

- 40 to 44 years

- 50 to 54 years

- 45 to 49 years

- 55 to 59 years

- 60 years and over

\section{Education}

Q1: What is the highest level of education you have ever completed?

- Secondary/high school graduation certificate or equivalent or less

- Diploma or certificate from a community college, CEGEP, institute of technology, nursing school, etc. or a trades certificate or diploma

- University certificate or diploma below the bachelor's level

- Bachelor's degree (e.g., BA, BSc) 
- University certificate or diploma above the bachelor's level including Master's degree (e.g., MA, MSc, MEd) or professional degree (e.g., LLB, degree in medicine, dentistry, veterinary medicine or optometry [MD, DDS, DMD, DVM, $\mathrm{OD}]$ ) or earned doctorate (e.g., $\mathrm{PhD}, \mathrm{DSc}, \mathrm{DEd})$

\section{Person-Job Fit}

Q2: My job is a good fit with my interests

Q2: My job is a good fit with my skills

\section{Job Satisfaction}

Q1: Overall, I like my job

Q2: 9 I get a sense of satisfaction from my work.

Q3: I am satisfied with my current work arrangement (e.g. regular work hours, telework, compressed work week)

Q4: I am satisfied with my department/agency

\section{Performance Feedback}

Q1: My immediate supervisor helps me determine my learning needs

Q2: I receive useful feedback from my immediate supervisor on my job performance Q3: My immediate supervisor assesses my work against identified goals and objectives Q4: I receive meaningful recognition from my immediate supervisor when I do a good job.

\section{Teamwork}

Q1: In my work unit, we work cooperatively as a team.

Q2: In my work unit, I believe that we hire people who can do the job.

Q3: My work unit provides high quality service to its clients

Q4: The people that I work with in my department or agency, readily share information with others who need it

\section{Stressful Work Environment}

Q1: I feel that the quality of my work suffers because of....

- A) Constantly changing priorities

- B) Lack of stability in my department or agency 
- C) Too many approval stages

- D) Unreasonable deadlines

- E) Having to do the same or more work, but with fewer resources

- F) High staff turnover

\section{Supervisor Support}

Q1: My immediate supervisor keeps me informed about the issues affecting my work Q2: I can count on my immediate supervisor to keep his or her promises.

Q3: If I were to suggest ways to improve how we do things, my immediate supervisor would take them seriously.

\section{Organizational Commitment}

Q1: I would prefer to remain with my work unit, even if a comparable job was available elsewhere in my department or agency.

Q2: I would prefer to remain with my department or agency, even if a comparable job was available elsewhere in the federal Public Service.

Q3: Based on my experience working in my department or agency, I would recommend it as a good place to work.

\section{Career Development and Opportunities}

Q1: I have opportunities to develop and apply the skills I need to enhance my career.

Q2: My department or agency does a good job of supporting employee career development.

Q3: I believe I have opportunities for promotion within my department or agency, given my education, skills and experience.

Q4: I believe I have opportunities for promotion within the Public Service, given my education, skills and experience. 


\section{Appendix C: Assumption Testing for Logistic Regression}

Multivariate Normality. Multivariate normality was assessed by examining the amount of multivariate outliers through the calculation of Mahalanobis distance. As noted in the data screening section, there were only 74 multivariate outliers present in the data set which is less than $1 \%$. Moreover, the t-tests conducted to examine the difference between the multivariate outliers and the other cases on demographic variables, failed to find any significant differences. Therefore, it can be assumed that the assumption of multivariate normality is met.

Linearity in the Logit. To test the assumption of linearity in the logit, new variables of each of the continuous variables were created that were a log transformation of the predictor variables. A logistic regression was performed which included all of the predictors variables, as well as an interaction term for each of the predictor variables by each of the variables log. The assumption is said to be met when the interaction terms fail to show a significant relationship to the outcome variable in relation to the untransformed variables. When all of the continuous predictors and interaction terms were added, the assumption was met for the following variables; person-job fit, job satisfaction, teamwork, stressful work environment, supervisory support, and organizational. The significance found for career development and opportunities may be due to the large sample size. As logistic regression is supposed to be robust to assumption violations, all predictor variables were used for subsequent analyses.

Multicollinearity. To test for multicollinearity, an assumption based on how similar the variables in the study are, the relationship between the independent and dependent variables were examined and a co-linearity test was conducted. As noted 
above, feedback and supervisor showed signs of multicollinearity and therefore were combined into the new variable of supervisory support. Using the new variable, there appears to be no signs of multicollinearity as the correlations between the independent and dependent variables are all under $r=0.8$. Also, the co-linearity test showed that person-job fit $(\mathrm{TOL}=.55, \mathrm{VIF}=1.81)$ job satisfaction $(\mathrm{TOL}=.45, \mathrm{VIF}=2.22)$, stressful work environment $(\mathrm{TOL}=.83, \mathrm{VIF}=1.21)$, teamwork $(\mathrm{TOL}=.56, \mathrm{VIF}=1.80)$, supervisory support $(\mathrm{TOL}=.58, \mathrm{VIF}=1.72)$, career development opportunities and opportunities (TOL $=.65, \mathrm{VIF}=1.55)$, and organizational commitment $(\mathrm{TOL}=.65, \mathrm{VIF}=1.55)$ all had tolerance values that exceeded .2 and variance inflation factor scores lower than 3 indicating a lack of multicollinearity for each included variable. Therefore, the assumption pertaining to a lack of multicollinearity between the variables was met.

Independence of errors. The assumption of independence of errors was tested by adding all of the continuous predictors into a multiple regression model with an item not being used in the study related to official languages, as the dependent variable. The Durbin-Watson stat was DW $=1.99$ which is not very different from 2 (Field, 2009). Furthermore using the equation $r=(2-D W) / 2$, the result was $r=.0055$ which is less than $r$ $=.15$ indicating that the assumption of independence of errors has not been violated. 